\title{
15. PETROLOGY AND GEOCHEMISTRY OF IGNEOUS ROCKS FROM ALLISON AND RESOLUTION GUYOTS, SITES 865 AND $866^{1}$
}

\author{
P.E. Baker, ${ }^{2}$ P.R. Castillo, ${ }^{3}$ and E. Condliffe ${ }^{2}$
}

\begin{abstract}
At Site 866 (Resolution Guyot), the volcanic basement ( $>1620 \mathrm{mbsf}$ and $<128 \mathrm{Ma}$ ) consists of a series of subaerial lava flows separated by scoriaceous, rubbly, and clay (iron-rich smectite) intervals. The lavas may be divided into three main groups on petrographic and geochemical grounds. Because of alteration, the geochemical evidence depends mainly on relatively immobile elements, such as $\mathrm{Ti}, \mathrm{Zr}, \mathrm{Nb}$, and the rare earth elements. The lowest group ( $>1727 \mathrm{mbsf}$ ) is picritic and alkalic (high $\mathrm{Nb} / \mathrm{Ti}$ and $\mathrm{Nb} / \mathrm{Zr}$ ). The middle group (1673-1727 mbsf), with megacrysts and phenocrysts of plagioclase, olivine, and clinopyroxene, is more markedly alkalic (e.g., steep mid-ocean ridge basalt-normalized light rare earth element-enriched patterns). The upper group (above $1673 \mathrm{mbs}$ ) includes basalts rich in plagioclase megacrysts overlain by picrites, and is more tholeiitic (lower $\mathrm{Nb} / \mathrm{Ti}, \mathrm{Zr} / \mathrm{Ti}$, and flatter rare earth element patterns). At Site 865 (Allison Guyot), altered basaltic sills are intrusive into Albian clayey dolomitic limestones between 830 and 870 mbsf. Several lines of evidence indicate that the sediment was unconsolidated at the time of invasion by the basalt $(<111 \mathrm{Ma})$. Salitic clinopyroxenes, abundances and ratios of the less mobile incompatible elements, and pronounced light rare earth element-enrichment all point to a decidedly more alkalic affinity than was seen at Site 866. Resolution and Allison guyots probably originated within the region of intense hotspot volcanism referred to as the South Pacific isotopic and thermal anomaly or SOPITA. The two guyots probably followed a similar tectonic pathway and may have passed over more than one hotspot. Geochemical evidence (e.g., $\mathrm{Nb} / \mathrm{Zr}$ and $\mathrm{Zr} / \mathrm{Ti}$ ) suggests that they have more in common with the Society-Austral (Tubuai) Islands than with islands to the east (e.g., Marquesas, Easter) or the west (Cook, Samoa): this is also consistent with lineaments derived by backtracking.
\end{abstract}

\section{INTRODUCTION}

A vast area of the South Pacific Ocean, about $3000 \mathrm{~km}$ across, was the site of intense mid-plate volcanism during the Early Cretaceous. The location of this activity probably corresponds with the present-day South Pacific Superswell (McNutt and Fischer, 1987), which includes the Society, Cook, and Austral archipelagos. It also belongs to SOPITA, the area of the so-called South Pacific isotopic and thermal anomaly (Staudigel et al., 1991). The lavas of these islands also form part of the isotopically distinct Southern Hemisphere belt referred to as the Dupal Anomaly (Hart, 1984). In the western part of the Mid-Pacific Mountains (MPM), a series of broad plateaus is surmounted by flattopped seamounts. The age of the oceanic crust beneath the MPM is estimated to be about 119 to 130 Ma near Allison Guyot and may be as old as $154 \mathrm{Ma}$ farther west, around Resolution Guyot (Sager, Winterer, Firth, et al., 1993). The guyots are capped by shallow-water limestones of Barremian-Albian age (124-98 Ma). The Cretaceous seamounts of the MPM probably formed over the South Pacific Superswell and were translated northwestward on zig-zag pathways, determined by changes in plate motion, to their present location (Fig. 1). From the hotspot lineaments calculated by Duncan and Clague (1985), the seamounts of Sites 865 and 866 lie close to the Easter Island track, but would have passed near the Marquesas and Society hotspots during their transit. A period of rejuvenation and uplift may have accompanied their passage over these other hotspots. The ages calculated by Duncan and Clague (1985) are consistent with the location of the guyots over the Marquesas or Society hotspots at 100 to $120 \mathrm{Ma}$.

Site 866 is discussed first, as it represents a substantial section through volcanic basement and was the only instance where basement was reached during Leg 143. At Site 865, on Allison Guyot, igneous

\footnotetext{
'Winterer, E.L., Sager, W.W., Firth, J.V., and Sinton, J.M. (Eds.), 1995. Proc, ODP. Sci. Results, 143: College Station, TX (Ocean Drilling Program).

${ }^{2}$ Department of Earth Sciences, University of Leeds, Leeds LS2 9JT, United Kingdom.

${ }^{3}$ Geological Research Division, Scripps Institution of Oceanography, University of California, San Diego, La Jolla, CA 92093-0220, U.S.A.
}

rocks are confined to a group of basaltic sills intruded into the sediments. Some comparisons are made with a few samples from Site 869 , on a sediment apron extending southward from Wodejebato Guyot and Pikinni Atoll. The detailed petrology and geochemistry of the volcaniclastics from Site 869 are treated separately (see Janney et al., this volume).

\section{ANALYTICAL METHODS}

$\mathrm{X}$-ray fluorescence (XRF) analyses for major and trace elements (excluding rare earth elements) were conducted at the Department of Earth Sciences, Leeds University, using a wavelength-dispersive automated Philips PW 1400 spectrometer. Major elements were determined on fused glass beads and trace elements on pressed powder pellets. Accuracy and precision for major elements are estimated at better than $3 \%$ for $\mathrm{Si}, \mathrm{Ti}, \mathrm{Fe}, \mathrm{Ca}$, and $\mathrm{K}$ and $7 \%$ for $\mathrm{Mg}, \mathrm{Na}, \mathrm{Al}, \mathrm{Mn}$, and $\mathrm{P}$ : for trace elements above $10 \mathrm{ppm}$ they are estimated at better than $10 \%$. Rare earth element (REE) determinations were performed on a VG Instruments PlasmaQuad II+ inductively coupled plasma mass spectrometer (ICPMS) at the Scripps Institution of Oceanography. Multiplier voltage was set at $5 \mathrm{kV}$ and nebulizing gas flow rate at 0.2 $\mathrm{L} / \mathrm{m}$. ${ }^{115} \mathrm{In}$ was used as an internal standard, and calibration was conducted using standard solutions of $5,10,50$ and $100 \mathrm{ppb}$ REE. Accuracy and precision of the analyses were monitored using the rock standards AGV-1 and BCR-1. Rock powders (0.014 g) were dissolved in clean Teflon vessels using $\approx 1 \mathrm{~mL} 2: 1$ mixture of concentrated $\mathrm{HF}$ and $\mathrm{HNO}_{3}$ and then heated overnight over a hot plate at low temperature. The resulting solution was evaporated to dryness, resuspended in a small amount of concentrated $\mathrm{HNO}_{3}$, and evaporated to dryness, and finally diluted to a factor of 1000 in a $1 \% \mathrm{HNO}_{3}$ solution containing $100 \mathrm{ppb}^{115} \mathrm{In}$. Accuracy of the analyses, based on repeated measurements of BCR-1 and AGV-1 standards, is better than $5 \%$, especially for the light elements.

Microprobe analyses were performed using a CAMECA SX-50 instrument fitted with three wavelength dispersive spectrometers and a LINK 10/55S energy dispersive system. Analysis conditions were as follows: 


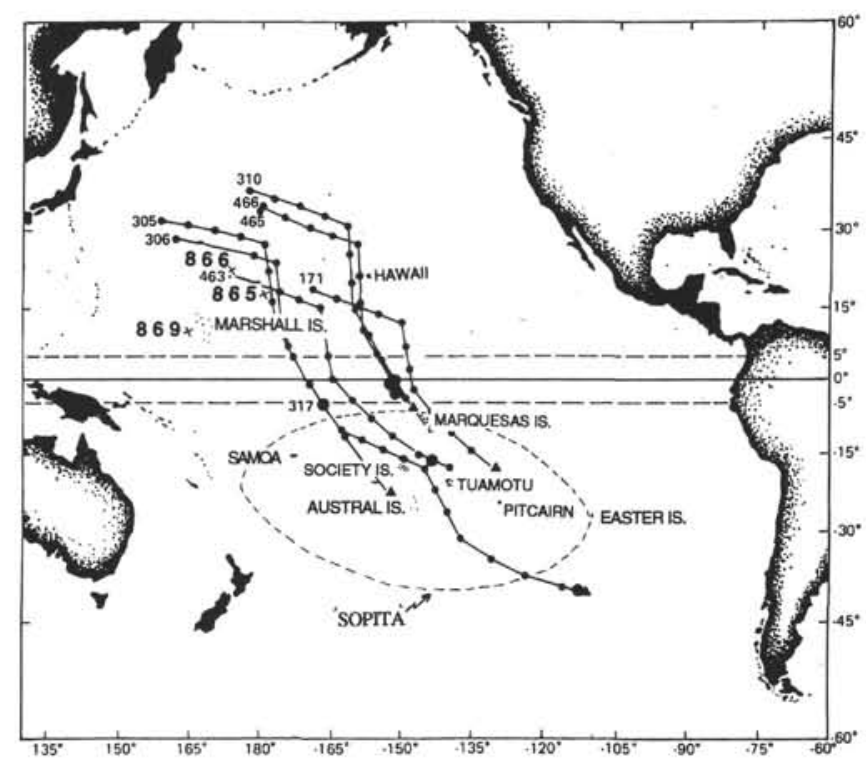

Figure 1. Location of Allison (Site 865) and Resolution (Site 866) guyots in relation to island groups and hotspot lineaments of the South Pacific (after Shipboard Scientific Party, 1981). Approximate location of SOPITA after Palacz and Saunders (1986).

1. Silicates and opaque oxides, excluding feldspars: beam energy, $15 \mathrm{kV}$; beam current, $15 \mathrm{nA}$; count times, $\mathrm{Na}, \mathrm{Mg}, \mathrm{Al}, \mathrm{Si}, \mathrm{K}, \mathrm{Ca}, \mathrm{Ti}$, all $15 \mathrm{~s}$ on peak and $10 \mathrm{~s}$ on background; $\mathrm{Cr}, \mathrm{Mn}, \mathrm{Fe}, \mathrm{Ni}, 30 \mathrm{~s}$ on peak and $20 \mathrm{~s}$ on background.

2. Feldspars: beam energy, $15 \mathrm{kV}$; beam current, $10 \mathrm{nA}$. Count times for all elements: $10 \mathrm{~s}$ on peak and $10 \mathrm{~s}$ on background. Where necessary, beam broadened to 2 or $3 \mu \mathrm{m}$ to prevent excessive element loss.

3. Raw counts were corrected for inter-elemental effects using CAMECA proprietary software.

4. Standards used: $\mathrm{Na}$, albite; $\mathrm{Mg}$, spinel; $\mathrm{Al}$, kyanite; $\mathrm{Si}$, diopside; $\mathrm{K}$, orthoclase; $\mathrm{Ca}$, wollastonite; $\mathrm{Ti}$, sphene; $\mathrm{Cr}$, chromite; $\mathrm{Mn}$, rhodonite; $\mathrm{Fe}$, haematite; and $\mathrm{Ni}$, nickel oxide.

\section{SITE 866}

Resolution Guyot $\left(21^{\circ} 19.9^{\prime} \mathrm{N}, 174^{\circ} 18.8^{\prime} \mathrm{E}\right)$ lies in $1373 \mathrm{~m}$ of water and consists of a 1620-m cap of shallow-water carbonates and pelagic sediments that rests on a topographically subdued volcanic structure rising only about $0.5 \mathrm{~km}$ above the general level of the MPM plateau. $\mathrm{K} / \mathrm{Ar}$ whole-rocks, whose ages inevitably are suspect with such highly altered states, yield ages in the range of 107 to $125 \mathrm{Ma}$ (Pringle et al., this volume). On the other hand, ${ }^{40} \mathrm{Ar} /{ }^{39} \mathrm{Ar}$ dates by the same authors give ages in the range of 120 to $129 \mathrm{Ma}$ (i.e., mid-Barremian to midAptian on Harland et al.'s [1990] time scale). Errors in the measurements are such that it is not possible to be certain whether this represents a simple succession of lava flows or whether there are also some intercalated sills. However, the new petrographic and geochemical data presented here show substantial petrologic variations in the basement of Resolution Guyot. It is now thought likely that the 125 -m-thick volcanic sequence drilled at Site 866 , originally interpreted as exclusively lava flows separated by rubbly intervals (Fig. 2), may contain some intrusive bodies. The average thickness of the flows and sills is estimated at about $10 \mathrm{~m}$, but poor recovery of the contacts and the friable nature of the interbasaltic beds probably means that they have been underestimated. The interbasaltic intervals range from clays to clast- or matrix-supported breccias in which the clasts are subangular to subrounded fragments of vesicular and amygdaloidal basalt, similar to the associated lava flows and sills. The matrix generally consists of reddish sandy clay; distinct layers of red clay also are found within the breccias (e.g., at interval 143-866A-180R-5, 54-57 cm). Fractures and cavities within the breccias also may be filled with red clay. X-ray diffraction (XRD) analysis of the clay indicates that it is an iron-rich smectite; some kaolinite also has been identified.

Most of the interbasaltic intervals are considered to be the products of various processes operating on a tropical or subtropical volcanic land surface. Each such interval probably represents decades or centuries as opposed to the span of perhaps hours or days required for emplacement of a single lava flow. Some of the interbasaltic intervals may represent oxidized soils, boles, or lateritic horizons. Other intervals probably represent the oxidized rubbly surface of aa flows, where weathering products have washed down to fill the intervening spaces. Some breccias may have formed as screes or been redistributed as mudflows or debris slides, but others may have been caused by the intrusion of sills. The fractured and porous nature of the Unit 7 breccia provided access for hydrothermal fluids and their precipitates. Veins and cavities are commonly filled with calcite, zeolites, clay minerals, and analcime.

\section{Petrography}

In the Leg 143 Initial Reports volume (Sager, Winterer, Firth, et al., 1993), the volcanic succession was divided into 12 units on the basis of the stratigraphic incidence of what originally were thought to be exclusively flows and interbasaltic intervals, without implying that these necessarily coincided with any petrographic differences. As a result of subsequent, and more detailed, investigations, petrographic and mineralogical compositional distinctions have now been drawn in respect of the lavas and sills and are shown in Figure 2. In summary, the different members are as follows:

Unit 1: A highly pyritized and calcified feldspathic basalt at the contact of the volcanic sequence with the overlying oolitic grainstone.

Unit 2: A very highly altered basalt containing abundant ilmenite and titanomagnetite in a matrix of alkali feldspar (e.g., Sample 143866A-171R-3, 70-73 cm)

Unit 5: An olivine-phyric basalt with about $7 \%$ fresh olivine phenocrysts $\left(\mathrm{Fo}_{87-75},<3 \mathrm{~mm}\right)$ and smaller plagioclase laths $\left(\mathrm{An}_{68-46}\right.$, $<0.5 \mathrm{~mm})$ in a matrix of clinopyroxene $\left(\mathrm{Ca}_{46} \mathrm{Mg}_{38} \mathrm{Fe}_{16}\right)$, magnetite, and feldspar. Cr-spinel crystals also occur (e.g., Sample 143-866A177B-1, 1-3 cm).

Unit 6: This is distinguished by the abundance (15\%) of plagioclase megacrysts and phenocrysts. Plagioclase megacrysts $(<10 \mathrm{~mm}$, $\left.\mathrm{An}_{81-36}\right)$ are accompanied by smaller plagioclase laths $(<2 \mathrm{~mm}$, $\left.\sim \mathrm{An}_{68}\right)$ and olivines $\left(<3 \mathrm{~mm}, \mathrm{Fo}_{82-67}\right)$. Examples of these plagioclasephyric basalts are Samples 143-866A-180R-3, 116-20 cm, and $-180 \mathrm{R}-4,1-4 \mathrm{~cm}$ ).

Units 8-11: Plagioclase megacrysts and/or phenocrysts are again common $(\sim 5 \%)$ in this group, but less abundant than in the overlying basalt described in Unit 6 . The large plagioclases $\left(\mathrm{An}_{71-63}\right)$ are locally accompanied by olivine $\left(\mathrm{Fo}_{86-74}\right)$ and clinopyroxene megacrysts $\left(\mathrm{Ca}_{45} \mathrm{Mg}_{41} \mathrm{Fe}_{13}\right)$. Examples are Samples 143-866A-182R-1, 102-105 $\mathrm{cm}$, and $-185 \mathrm{R}-3,88-92 \mathrm{~cm}$.

Unit 12: Olivine-phyric basalt, similar to that of Unit 5. Olivines $(<3 \mathrm{~mm})$ make up about $8 \%$ of the volume and are accompanied by scattered feldspar megacrysts $(<6 \mathrm{~mm})$. Olivine compositions are in the range $\mathrm{Fo}_{83-76}$, and the feldspars are about $\mathrm{An}_{70}$. As in Unit 5, some $\mathrm{Cr}$-spinels occur. Interstitial groundmass feldspar has a composition of $\mathrm{Or}_{19} \mathrm{Ab}_{71} \mathrm{An}_{10}$.

\section{Mineral Chemistry}

A wide range of feldspar compositions is represented in the Resolution Guyot volcanic succession. Megacrysts and phenocrysts of plagioclase are common throughout the sequence of lavas. Zoned, mostly within the labradorite range, they attain their most calcic com- 


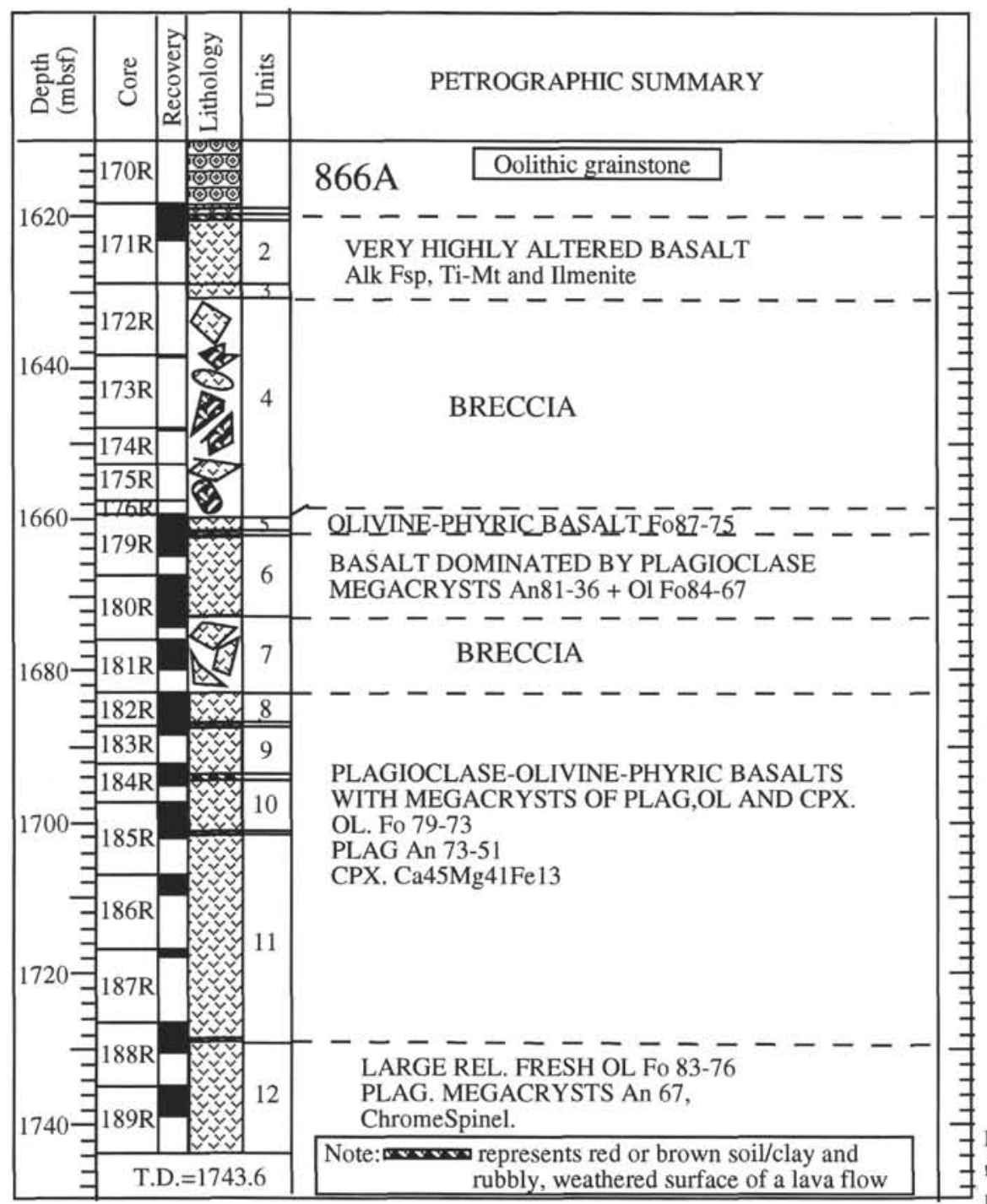

Figure 2. Stratigraphic succession in the volcanic basement of Resolution Guyot (Hole 866A) indicating major petrographic groupings distinguished within the lavas.

position $\left(A n_{81}\right)$ in the feldspar-phyric lavas of Unit 6 . The wide range of feldspar compositions (Fig. 3 and Table 1) is partly attributable to magmatic processes, but probably also is the consequence of submarine weathering and exchange. Some interstitial groundmass feldspar is of albite composition and some is almost pure $\mathrm{K}$-feldspar.

Olivine is invariably partially altered to, or wholly pseudomorphed by, serpentine minerals and iron oxides. The most magnesian compositions occur in lavas where olivine attains its maximum modal abundance (i.e., Unit $5\left[\mathrm{Fo}_{87}\right]$ and Unit $\left.12\left[\mathrm{Fo}_{83}\right]\right)$. Phenocrysts are normally zoned to a minimum forsterite content of $\mathrm{Fo}_{65}$ at the rims (Table 2).

Clinopyroxene occurs as megacrysts in the central part of the volcanic sequence (Units 8-11), and occasionally appears as microphenocrysts; it is also a ubiquitous groundmass constituent. The clinopyroxene megacrysts in Sample 143-866A-182R-1, 102-105 cm, have a composition of $\mathrm{Ca}_{45} \mathrm{Mg}_{42} \mathrm{Fe}_{13}$. In Sample 143-866A-185R-3, 88-92 cm, the megacrysts show sector zoning from $\mathrm{Ca}_{43} \mathrm{Mg}_{42} \mathrm{Fe}_{15}$ to $\mathrm{Ca}_{41} \mathrm{Mg}_{34} \mathrm{Fe}_{25}$, the latter being the most iron-rich pyroxene composition in the Resolution Guyot volcanics. A typical groundmass composition is $\mathrm{Ca}_{44} \mathrm{Mg}_{39} \mathrm{Fe}_{17}$ (Sample 143-866A-177B-1, 1-3 cm). Projections of pyroxene compositions in terms of relative proportions of $\mathrm{Ca}-\mathrm{Mg}-\mathrm{Fe}$ (Fig. 4) show a concentration of points in the augite field with a small scattering toward $\mathrm{Ca}$ depletion and $\mathrm{Fe}$ enrichment. There is remarkably little overlap with the clinopyroxenes of Sites 865 and
869. Schweitzer et al. (1979) demonstrated how differences in pyroxene composition reflect differences in the type of basalt in which they occur. They point, for example, to higher $\mathrm{Cr}_{2} \mathrm{O}_{3}$ and lower $\mathrm{TiO}_{2}$ in tholeiitic as opposed to alkalic pyroxenes. Higher $\mathrm{TiO}_{2}$ and lower $\mathrm{Cr}_{2} \mathrm{O}_{3}$ concentrations occur in the pyroxenes from Hole $865 \mathrm{~A}$ as compared with Hole 866A (Fig. 5 and Tables 3 and 4), indicative of the more alkalic nature of the former. The Site 866 pyroxenes tend to be concentrated in the augite field with a trend toward subcalcic ferroaugite. Fodor et al. (1975) demonstrated the different chemical characteristics of pyroxenes from the tholeiitic, alkalic, and nephelinic suites of Hawaii. On the ternary diagram (Fig. 4), pyroxenes of Site 865 plot largely in the salite field and are generally more calcic than those of Site 866. A high Wo component in clinopyroxenes has been shown by both Le Bas (1962) and Fodor et al. (1975) to be a feature of highly alkalic or nephelinic lavas.

Oxide phases are mainly titanomagnetite, but include ilmenite (e.g., Samples 143-866A-177B-1, 1-3 cm and -185R-2, 62-66 cm) and chrome spinel (e.g., Sample 143-866A-185-3, 88-92 cm) (Table 5).

Much of the matrix of the lavas has been altered to smectite, as confirmed by XRD. Electron microprobe analysis (e.g., $21 \% \mathrm{FeO}$ and $15 \% \mathrm{MgO}$ in Sample 143-866 A-181-3, 91-96 cm) indicates an iron- and magnesium-rich clay, approximate in composition to ferroan saponite. 
Table 1. Representative microprobe analyses (wt \% oxide) and atomic proportions of feldspars in basaltic rocks from Holes 865A and 866A.

\begin{tabular}{|c|c|c|c|c|c|c|c|c|c|c|c|}
\hline Core, section: & $865 \mathrm{~A}-94 \mathrm{R}-4$ & $865 A-93 R-3$ & $865 A-93 R-3$ & 865A-91R-1 & $866 \mathrm{~A}-189 \mathrm{R}-1$ & $866 \mathrm{~A}-186 \mathrm{R}-3$ & $866 \mathrm{~A}-185 \mathrm{R}-3$ & $866 \mathrm{~A}-182 \mathrm{R}-3$ & $866 \mathrm{~A}-182 \mathrm{R}-1$ & $866 \mathrm{~A}-180 \mathrm{R}-4$ & $866 \mathrm{~A}-180 \mathrm{R}-3$ \\
\hline \multirow[t]{2}{*}{ Interval $(\mathrm{cm})$ : } & $78-80$ & $13-17$ & $13-17$ & $128-130$ & $66-69$ & $12-15$ & $88-92$ & $48-51$ & $102-105$ & $1-4$ & $116-120$ \\
\hline & (Lath) & (Lath) & (Gmass) & (Lath) & (Gmass) & (Large K fsp) & (Gmass) & (Phen core) & (Phen core) & (Mega core) & (Phen core) \\
\hline $\mathrm{SiO}_{2}$ & 50.29 & 50.71 & 64.07 & 51.49 & 51.58 & 65.11 & 54.14 & 49.39 & 51.35 & 48.84 & 50.40 \\
\hline $\mathrm{Al}_{2} \mathrm{O}_{3}$ & 30.61 & 30.48 & 18.77 & 29.60 & 29.47 & 18.28 & 27.81 & 31.08 & 29.76 & 31.75 & 31.03 \\
\hline $\mathrm{Fe}_{2} \mathrm{O}_{3}$ & 0.66 & 0.65 & 0.13 & 0.72 & 0.90 & 0.08 & 1.28 & 0.88 & 0.74 & 0.72 & 0.54 \\
\hline $\mathrm{MnO}$ & 0.06 & 0.00 & 0.00 & 0.09 & 0.03 & 0.00 & 0.11 & 0.00 & 0.08 & 0.00 & 0.08 \\
\hline $\mathrm{MgO}$ & 0.12 & 0.06 & 0.00 & 0.10 & 0.16 & 0.00 & 0.11 & 0.29 & 0.06 & 0.24 & 0.08 \\
\hline $\mathrm{CaO}$ & 14.76 & 14.52 & 0.03 & 13.77 & 13.58 & 0.00 & 11.70 & 15.40 & 13.98 & 16.23 & 15.40 \\
\hline $\mathrm{Na}_{2} \mathrm{O}$ & 2.82 & 3.02 & 0.41 & 3.49 & 3.87 & 0.22 & 4.94 & 2.71 & 3.68 & 2.53 & 3.08 \\
\hline $\mathrm{K}_{2} \mathrm{O}$ & 0.38 & 0.24 & 15.94 & 0.51 & 0.17 & 16.57 & 0.22 & 0.09 & 0.10 & 0.03 & 0.07 \\
\hline Total & 99.70 & 99.68 & 99.36 & 99.75 & 99.96 & 100.27 & 100.29 & 100.31 & 99.75 & 100.34 & 100.67 \\
\hline $\mathrm{Si}$ & 2.306 & 2.321 & 2.979 & 2.357 & 2.359 & 3.004 & 2.453 & 2.267 & 2.349 & 2.235 & 2.291 \\
\hline $\mathrm{Al}$ & 1.654 & 1.644 & 1.028 & 1.596 & 1.588 & 0.994 & 1.485 & 1.681 & 1.604 & 1.712 & 1.662 \\
\hline $\mathrm{Fe}^{3}$ & 0.023 & 0.022 & 0.005 & 0.025 & 0.031 & 0.003 & 0.043 & 0.030 & 0.026 & 0.025 & 0.018 \\
\hline Mn & 0.002 & 0.000 & 0.000 & 0.003 & 0.001 & 0.000 & 0.004 & 0.000 & 0.003 & 0.000 & 0.003 \\
\hline $\mathrm{Mg}$ & 0.008 & 0.004 & 0.000 & 0.007 & 0.011 & 0.000 & 0.007 & 0.020 & 0.004 & 0.016 & 0.005 \\
\hline $\mathrm{Ca}$ & 0.725 & 0.712 & 0.002 & 0.675 & 0.665 & 0.000 & 0.568 & 0.757 & 0.685 & 0.795 & 0.750 \\
\hline $\mathrm{Na}$ & 0.250 & 0.268 & 0.037 & 0.310 & 0.343 & 0.020 & 0.434 & 0.241 & 0.326 & 0.225 & 0.271 \\
\hline K & 0.022 & 0.014 & 0.945 & 0.030 & 0.010 & 0.975 & 0.013 & 0.006 & 0.006 & 0.002 & 0.004 \\
\hline Total & 4.990 & 4.985 & 4.996 & 5.003 & 5.008 & 4.996 & 5.007 & 5.002 & 5.003 & 5.010 & 5.004 \\
\hline $\mathrm{Ab}$ & 25.11 & 26.93 & 3.77 & 30.51 & 33.69 & 2.00 & 42.78 & 24.02 & 32.06 & 21.99 & 26.46 \\
\hline Or & 2.20 & 1.43 & 96.06 & 2.95 & 1.00 & 98.00 & 1.26 & 0.55 & 0.58 & 0.19 & 0.40 \\
\hline An & 72.69 & 71.64 & 0.17 & 66.54 & 65.31 & 0.00 & 55.96 & 75.43 & 67.37 & 77.82 & 73.15 \\
\hline
\end{tabular}

Note: Lath = plagioclase lath, Gmass = groundmass, Large $\mathrm{K}$ fsp = large $\mathrm{K}$ feldspar, Phen core = phenocryst core, and Mega core $=$ megacryst core .

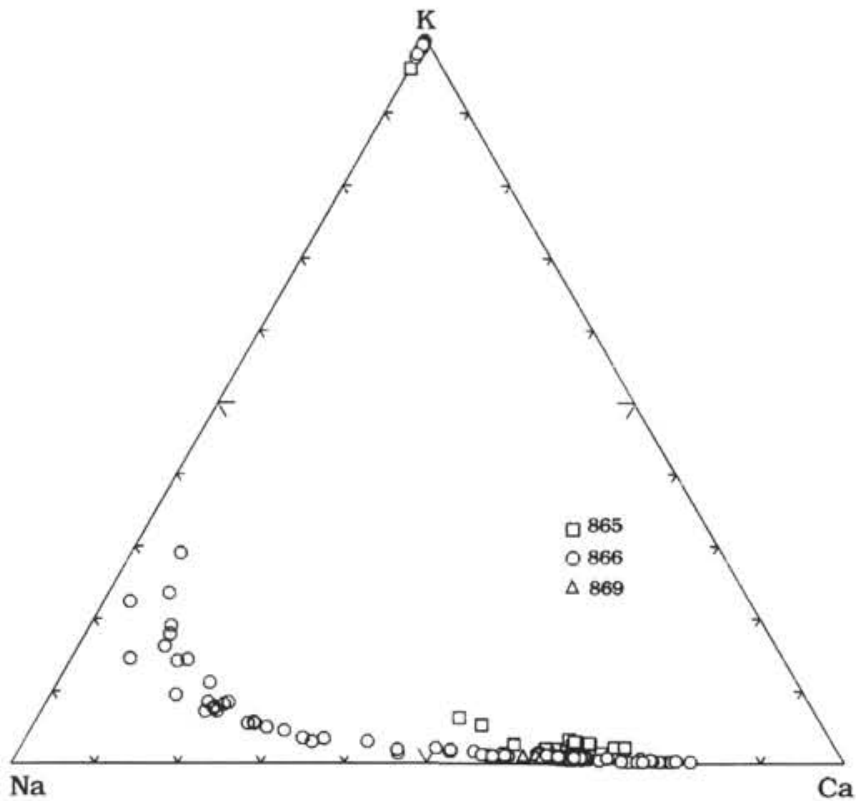

Figure 3. Compositional variations of feldspars from Sites 865 and 866 with Site 869 for comparison.

\section{Geochemistry}

Representative whole-rock X-ray fluorescence (XRF) analyses for major and trace elements are presented in Table 6. Except for some pieces of slightly altered basalts from Core 143-866A-177B, all of the volcanic rocks have been moderately to completely altered, mainly to clay minerals. Thus, little significance can be attached to the present concentrations of the more mobile elements (e.g., $\mathrm{K}_{2} \mathrm{O}, \mathrm{Na}_{2} \mathrm{O}$ ). However, plots of major oxides vs. stratigraphic height in the volcanic succession reveal broad compositional changes that are probably insensitive to finer-scale variations caused by alteration. In a plot of $\mathrm{MgO}$ vs. depth (Fig. 6A), the only clear distinction is between a group of $\mathrm{MgO}$-rich lavas below $1730 \mathrm{mbsf}$ and generally less magnesian lavas higher up the succession. The more magnesian lavas coincide

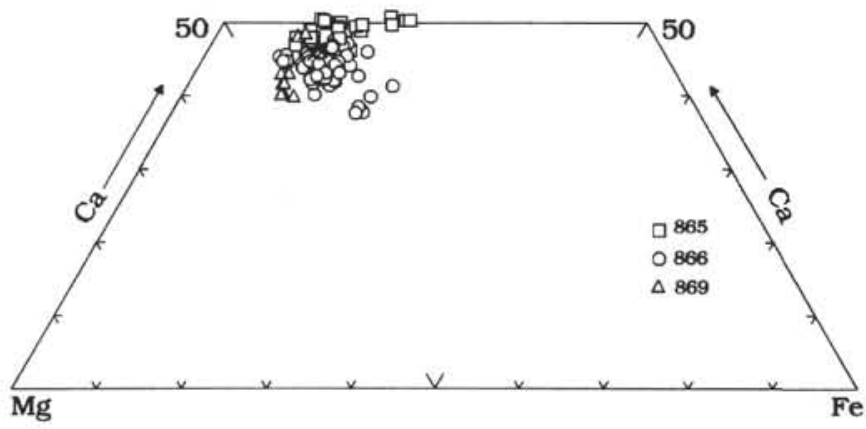

Figure 4. Pyroxene quadrilateral showing compositions of clinopyroxenes from Sites 865 and 866 , with samples from Site 869 for comparison.

with those identified as the olivine-phyric group of Unit 12 , and the most magnesian of the remainder is equivalent to the thin olivinephyric Unit 5 . A cluster of relatively low-MgO, more differentiated lavas occurs in the middle part of the succession (1690-1710 mbsf). In terms of $\mathrm{Al}_{2} \mathrm{O}_{3}$ vs. depth (Fig. 6B), this also distinguishes an $\mathrm{Al}_{2} \mathrm{O}_{3}$-depleted group, corresponding to the Unit 12 olivine-phyric lavas, and a cluster of $\mathrm{Al}_{2} \mathrm{O}_{3}$-enriched lavas $\left(17 \%-18 \% \mathrm{Al}_{2} \mathrm{O}_{3}\right)$, corresponding to the plagioclase-phyric suite of Unit 6. A plot of $\mathrm{Fe}_{2} \mathrm{O}_{3} /$ $\mathrm{MgO}$ vs. depth (Fig. 6C) separates the lowermost group (Unit 12) from the rest as having lower $\mathrm{Fe} / \mathrm{Mg}$ ratios. From $1710 \mathrm{mbsf}$ upward, there is a general, though not sharply defined, shift from higher to lower $\mathrm{Fe} / \mathrm{Mg}$ ratios.

Studies of the alteration of submarine lavas (e.g., Cann, 1970; Hart et al., 1974) have shown that elements such as $\mathrm{Ti}, \mathrm{Zr}, \mathrm{Nb}, \mathrm{Y}$, and most of the REE are not strongly affected during seawater alteration of basalt. In a plot of $\mathrm{TiO}_{2}$ vs. depth (Fig. 7A) three major geochemical groups are apparent: the Unit 12 lavas with low $\mathrm{TiO}_{2}$, the Units 8-11 group with high $\mathrm{TiO}_{2}$, and a later group, above $1673 \mathrm{mbsf}$, which again has lower $\mathrm{TiO}_{2}$ but indicates a trend toward higher concentrations with decreasing depth. However, it is plots of $\mathrm{Zr}, \mathrm{Nb}$, and REE that are the most illuminating. A plot of $\mathrm{Nb} / \mathrm{Zr}$ vs. depth (Fig. 7B) distinguishes the uppermost plagioclase-phyric lavas from Unit 6 from the rest of the lavas, because these samples are displaced to lower $(0.13-0.15) \mathrm{Nb} / \mathrm{Zr}$ ratios. The olivine-phyric lavas from Units 5 and 10 and the lowermost portion of Unit 12 have intermediate 
Table 1 (continued).

\begin{tabular}{ccc}
\hline $\begin{array}{c}\text { 866A-179R-5 } \\
\text { 866A-177B-1 }\end{array}$ & $866 \mathrm{~A}-177 \mathrm{~B}-1$ \\
& $1-3$ & $1-3$ \\
(Phen core) & (Phen core) & (Lath) \\
\hline 48.54 & 51.06 & 56.72 \\
30.95 & 29.38 & 26.13 \\
0.66 & 0.92 & 0.62 \\
0.10 & 0.14 & 0.03 \\
0.11 & 0.19 & 0.11 \\
15.95 & 14.39 & 9.60 \\
2.82 & 3.65 & 6.12 \\
0.06 & 0.13 & 0.26 \\
99.18 & 99.85 & 99.59 \\
& & \\
2.249 & 2.340 & 2.565 \\
1.691 & 1.587 & 1.393 \\
0.023 & 0.032 & 0.021 \\
0.004 & 0.006 & 0.001 \\
0.007 & 0.013 & 0.008 \\
0.792 & 0.707 & 0.465 \\
0.254 & 0.324 & 0.536 \\
0.003 & 0.007 & 0.015 \\
5.023 & 5.016 & 5.004 \\
24.18 & 31.23 & 52.76 \\
0.32 & 0.71 & 1.47 \\
75.50 & 68.06 & 45.77 \\
& & \\
& &
\end{tabular}

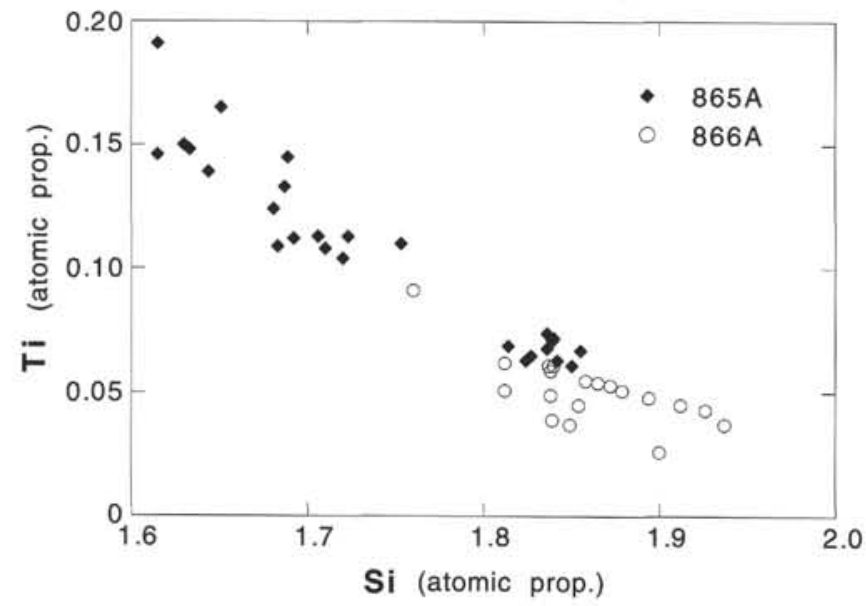

Figure 5. Ti vs. $\mathrm{Si}$ (cation proportions on basis of 6 oxygens) in clinopyroxenes from Holes $865 \mathrm{~A}$ and $866 \mathrm{~A}$.

$(0.15-0.18) \mathrm{Nb} / \mathrm{Zr}$ ratios, whereas the remainder of the volcanic succession, consisting of Units 7,8,9, and 11 as well as the upper portion of Unit 12 , has high $(0.19-0.22) \mathrm{Nb} / \mathrm{Zr}$ ratios.

Chondrite-normalized patterns and total concentrations of REE (Fig. 8A) reinforce the three-fold subdivision of the lavas drawn from the ratio of immobile incompatible elements $\mathrm{Nb}$ and $\mathrm{Zr}$. The REE contents of the low $\mathrm{Nb} / \mathrm{Zr}$ basalts from the uppermost part of the succession (i.e., above $1673 \mathrm{mbsf}$ ) are only 8 to 60 times chondritic values. More importantly, they have flattened light REE patterns. The relative enrichment of the light to middle REE, represented by $\mathrm{La} / \mathrm{Sm}$ ratio, for these uppermost basalts is low ( 1.4-1.8; Fig. 7C). Conversely, the REE contents of the high $\mathrm{Nb} / \mathrm{Zr}$ basalts from the middle and lower portions of the succession are 10 to 130 times chondritic values. These samples also are enriched in light REE, having high ( 2.4-2.9) $\mathrm{La} / \mathrm{Sm}$ ratios. Lavas with intermediate $\mathrm{Nb} / \mathrm{Zr}$ ratios from the middle to lower portions of the Hole $866 \mathrm{~A}$ basement have 10 to 90 times chondritic values in their REE contents; these lavas are only moderately enriched in light $\mathrm{REE}(\mathrm{La} / \mathrm{Sm} \sim 0.15-0.18)$. It is important to note, however, that the intermediate group generally overlaps with both the low and high $\mathrm{Nb} / \mathrm{Zr}$ groups, but more so with the former in
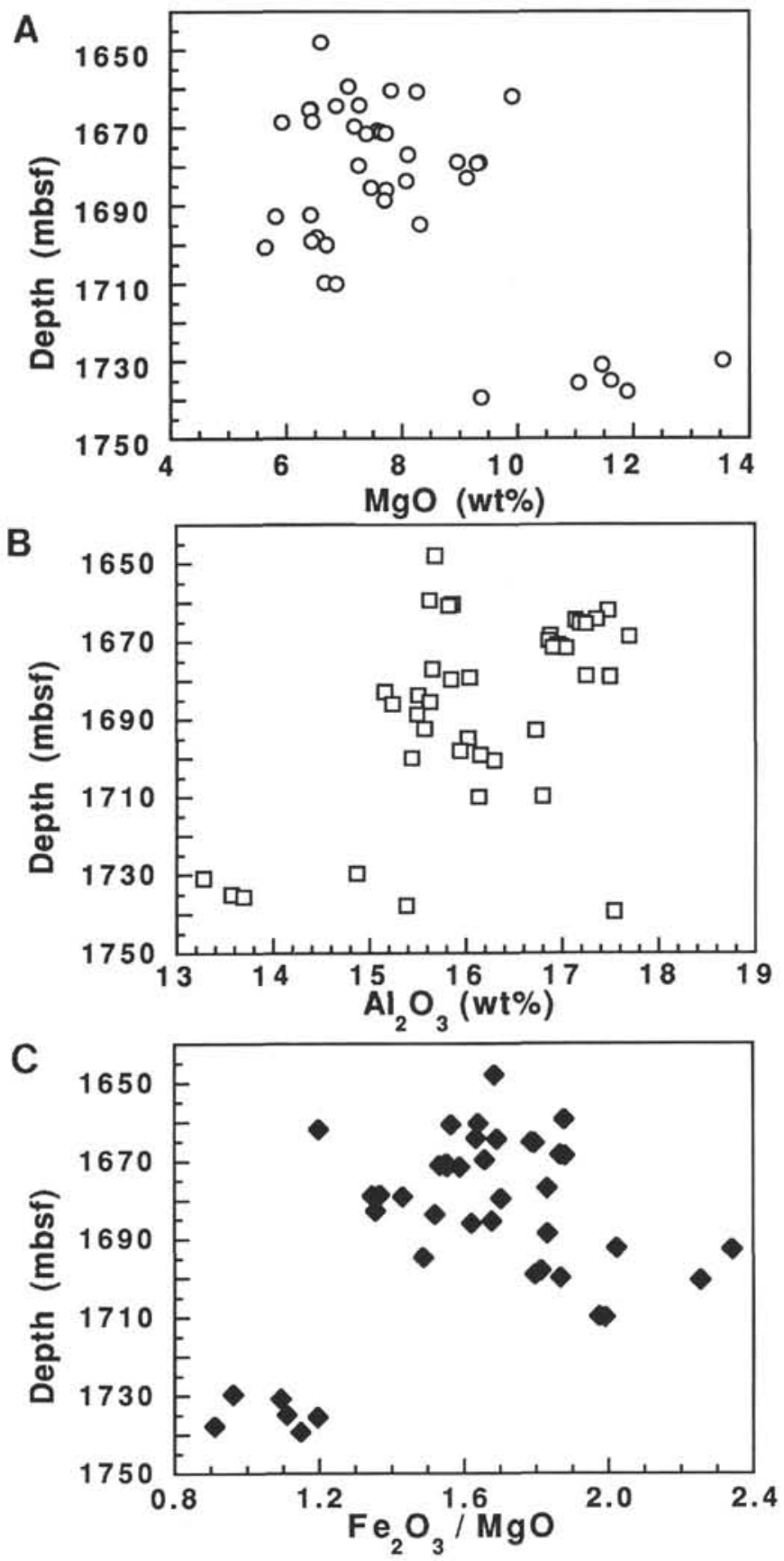

Figure 6. A. Concentration of $\mathrm{MgO}$ with depth in the volcanic rocks of Hole 866A. Note the more magnesian lavas below $1730 \mathrm{mbsf}$ and the cluster of more differentiated, low-MgO flows, around $1700 \mathrm{mbsf}$. B. Concentration of $\mathrm{Al}_{2} \mathrm{O}_{3}$ with depth in the volcanic rocks of Hole $866 \mathrm{~A}$. C. Plot of $\mathrm{Fe}_{2} \mathrm{O}_{3} / \mathrm{MgO}$ (atomic) vs. depth in the volcanic rocks of Hole 866A.

terms of concentrations and light-REE enrichment. Specifically, the Unit 5 lavas belong to the less light REE-enriched group despite their intermediate $\mathrm{Nb} / \mathrm{Zr}$ ratios. The three-fold subdivision of Site 866 samples into low $\mathrm{Nb} / \mathrm{Zr}$, high $\mathrm{Nb} / \mathrm{Zr}$, and intermediate $\mathrm{Nb} / \mathrm{Zr}$ geochemical lava groups, as well as the conflicting behavior of the latter group, are clearly shown in a plot of $\mathrm{La} / \mathrm{Sm}$ vs. $\mathrm{Nb} / \mathrm{Zr}$ ratios (Fig. 9).

Plots of $\mathrm{Nb}$ and $\mathrm{Zr}$ vs. $\mathrm{TiO}_{2}$ (Figs. 10A and 10B) also clearly separate the low $\mathrm{Nb} / \mathrm{Zr}$ and high $\mathrm{Nb} / \mathrm{Zr}$ Site 866 lavas, which are also evident in Figure 11. The plagioclase phyric lavas from above $1673 \mathrm{mbsf}$ contain lower $\mathrm{Nb}$ and $\mathrm{Zr}$ for given $\mathrm{TiO}_{2}$ than do the plagioclaseolivine-phyric basalts from below 1673 mbsf. The intermediate 
Table 2. Representative microprobe analyses (wt\% oxide) and atomic proportions of olivines from basaltic rocks in Hole 866A.

\begin{tabular}{|c|c|c|c|c|c|c|c|c|c|c|c|}
\hline Core, section: & $189 \mathrm{R}-1$ & $189 \mathrm{R}-1$ & $182 \mathrm{R}-3$ & $182 \mathrm{R}-3$ & $182 R-3$ & $182 \mathrm{R}-1$ & $182 \mathrm{R}-1$ & $180 \mathrm{R}-4$ & $180 \mathrm{R}-4$ & $180 \mathrm{R}-3$ & $180 \mathrm{R}-3$ \\
\hline \multirow[t]{2}{*}{ Interval $(\mathrm{cm})$ : } & $66-69$ & $66-69$ & $48-51$ & $48-51$ & $48-51$ & $102-105$ & $102-105$ & $1-4$ & $1-4$ & $116-120$ & $116-120$ \\
\hline & (Phen core) & (Large unzoned) & (Phen relict) & (Phen rim) & (Mega core) & (Phen core) & (Phen rim) & (Phen core) & (Phen rim) & (Phen core) & (Phen rim) \\
\hline $\mathrm{SiO}_{2}$ & 39.70 & 38.46 & 39.43 & 38.08 & 39.18 & 40.92 & 38,73 & 39.84 & 37.23 & 40.45 & 37.35 \\
\hline $\mathrm{TiO}_{2}$ & 0.01 & 0.04 & 0.07 & 0.02 & 0.05 & 0.01 & 0.05 & 0.06 & 0.05 & 0.05 & 0.09 \\
\hline $\mathrm{Al}_{2} \mathrm{O}_{3}$ & 0.06 & 0.04 & 0.04 & 0.04 & 0.03 & 0.09 & 0.06 & 0.08 & 0.04 & 0.05 & 0.03 \\
\hline $\mathrm{FeO}$ & 15.36 & 21.39 & 18.48 & 23.80 & 19.85 & 13.42 & 23.54 & 17.04 & 28.56 & 13.32 & 30.76 \\
\hline $\mathrm{MnO}$ & 0.22 & 0.28 & 0.19 & 0.41 & 0.35 & 0.09 & 0.32 & 0.28 & 0.41 & 0.22 & 0.46 \\
\hline $\mathrm{MgO}$ & 43.59 & 39.03 & 41.11 & 36.12 & 40.35 & 45.22 & 37.27 & 42.26 & 32.58 & 45.55 & 32.18 \\
\hline $\mathrm{CaO}$ & 0.29 & 0.26 & 0.27 & 0.33 & 0.27 & 0.24 & 0.26 & 0.28 & 0.41 & 0.25 & 0.35 \\
\hline $\mathrm{NiO}$ & 0.24 & 0.11 & 0.13 & 0.12 & 0.19 & 0.34 & 0.22 & 0.28 & 0.10 & 0.33 & 0.17 \\
\hline Total & 99.47 & 99.61 & 99.72 & 98.91 & 100.26 & 100.33 & 100.46 & 100.12 & 99.37 & 100.22 & 101.38 \\
\hline $\mathrm{Si}$ & 1.005 & 1.001 & 1.009 & 1.010 & 1.005 & 1.015 & 1.009 & 1.009 & 1.007 & 1.006 & 1.000 \\
\hline $\mathrm{Ti}$ & 0.000 & 0.001 & 0.001 & 0.000 & 0.001 & 0.000 & 0.001 & 0.001 & 0.001 & 0.001 & 0.002 \\
\hline $\mathrm{Al}$ & 0.002 & 0.001 & 0.001 & 0.001 & 0.001 & 0.003 & 0.002 & 0.002 & 0.001 & 0.002 & 0.001 \\
\hline $\mathrm{Fe}^{2}$ & 0.325 & 0.466 & 0.395 & 0.528 & 0.426 & 0.278 & 0.513 & 0.361 & 0.646 & 0.277 & 0.689 \\
\hline $\mathrm{Mn}$ & 0.005 & 0.006 & 0.004 & 0.009 & 0.008 & 0.002 & 0.007 & 0.006 & 0.009 & 0.005 & 0.010 \\
\hline $\mathrm{Mg}$ & 1.645 & 1.514 & 1.568 & 1.428 & 1.542 & 1.672 & 1.447 & 1.596 & 1.313 & 1.689 & 1.284 \\
\hline $\mathrm{Ca}$ & 0.008 & 0.007 & 0.008 & 0.009 & 0.008 & 0.006 & 0.007 & 0.008 & 0.012 & 0.007 & 0.010 \\
\hline $\mathrm{Ni}$ & 0.005 & 0.002 & 0.003 & 0.003 & 0.004 & 0.007 & 0.005 & 0.006 & 0.002 & 0.007 & 0.004 \\
\hline Total & 2.995 & 2.998 & 2.989 & 2.988 & 2.995 & 2,983 & 2.991 & 2.989 & 2.991 & 2.994 & 3.000 \\
\hline Fo & 83.3 & 76.2 & 79.7 & 72.7 & 78.1 & 85.7 & 73.6 & 81.3 & 66.7 & 85.7 & 64.7 \\
\hline
\end{tabular}

Note: Phen core $=$ phenocryst core, Phen relict $=$ phenocryst relict, Phen rim $=$ phenocryst rim, and Mega core = megacryst core.

Table 3. Representative microprobe analyses (wt \% oxide) and atomic proportions of clinopyroxenes from basaltic rocks in Hole 866A.

\begin{tabular}{|c|c|c|c|c|c|c|c|c|c|c|}
\hline Core, section: & $189 \mathrm{R}-1$ & $186 \mathrm{R}-3$ & 186R-3 & $186 \mathrm{R}-3$ & $185 \mathrm{R}-3$ & $185 \mathrm{R}-3$ & $182 \mathrm{R}-1$ & $181 R-3$ & $180 \mathrm{R}-4$ & $180 R-3$ \\
\hline Interval $(\mathrm{cm})$ : & $\begin{array}{c}66-69 \\
\text { (Gmass) }\end{array}$ & $\begin{array}{c}12-15 \\
\text { (Mega core) }\end{array}$ & $\begin{array}{c}12-15 \\
\text { (Mega rim) }\end{array}$ & $\begin{array}{c}12-15 \\
\text { (Gmass) }\end{array}$ & $\begin{array}{c}88-92 \\
\text { (Megacryst) }\end{array}$ & $\begin{array}{c}88-92 \\
\text { (Mega rim) }\end{array}$ & $\begin{array}{c}\text { 102-105 } \\
\text { (Phen core) }\end{array}$ & $\begin{array}{c}\text { 91-96 } \\
\text { (Small cryst) }\end{array}$ & $\begin{array}{c}1-4 \\
\text { (Small cryst) }\end{array}$ & $\begin{array}{l}116-20 \\
\text { (Gmass) }\end{array}$ \\
\hline $\begin{array}{l}\mathrm{SiO}_{2} \\
\mathrm{TiO}_{2} \\
\mathrm{Al}_{2} \mathrm{O}_{3} \\
\mathrm{Cr}_{2} \mathrm{O}_{3} \\
\mathrm{Fe}_{2} \mathrm{O}_{3} \\
\mathrm{FeO} \\
\mathrm{MnO} \\
\mathrm{MgO} \\
\mathrm{CaO} \\
\mathrm{Na}_{2} \mathrm{O} \\
\text { Total }\end{array}$ & $\begin{array}{r}50.62 \\
1.14 \\
2.89 \\
0.54 \\
2.04 \\
5.43 \\
0.19 \\
15.09 \\
21.25 \\
0.39 \\
99.58\end{array}$ & $\begin{array}{r}50.32 \\
0.91 \\
4.94 \\
0.52 \\
1.93 \\
4.46 \\
0.09 \\
15.45 \\
21.32 \\
0.35 \\
100.28\end{array}$ & $\begin{array}{r}49.84 \\
0.97 \\
4.77 \\
0.67 \\
2.49 \\
3.71 \\
0.10 \\
15.67 \\
21.16 \\
0.35 \\
99.73\end{array}$ & $\begin{array}{r}49.30 \\
2.12 \\
3.30 \\
0.00 \\
3.51 \\
5.99 \\
0.24 \\
14.69 \\
20.52 \\
0.46 \\
100.13\end{array}$ & $\begin{array}{r}49.51 \\
1.65 \\
3.63 \\
0.04 \\
2.58 \\
6.76 \\
0.20 \\
14.44 \\
20.47 \\
0.38 \\
99.66\end{array}$ & $\begin{array}{r}50.51 \\
1.21 \\
2.85 \\
0.02 \\
2.29 \\
6.93 \\
0.32 \\
14.77 \\
20.26 \\
0.42 \\
99.58\end{array}$ & $\begin{array}{r}49.44 \\
2.15 \\
2.86 \\
0.05 \\
1.72 \\
10.16 \\
0.31 \\
12.76 \\
19.96 \\
0.49 \\
99.89\end{array}$ & $\begin{array}{r}46.62 \\
3.11 \\
5.38 \\
0.11 \\
3.92 \\
7.07 \\
0.26 \\
12.65 \\
20.28 \\
0.58 \\
99.97\end{array}$ & $\begin{array}{r}50.80 \\
1.57 \\
2.19 \\
0.02 \\
1.99 \\
7.06 \\
0.27 \\
14.05 \\
21.48 \\
0.49 \\
99.90\end{array}$ & $\begin{array}{r}50.28 \\
1.66 \\
3.30 \\
0.05 \\
2.31 \\
6.34 \\
0.26 \\
14.07 \\
21.54 \\
0.51 \\
100.31\end{array}$ \\
\hline $\begin{array}{l}\mathrm{Si} \\
\mathrm{Ti} \\
\mathrm{Al} \\
\mathrm{Cr} \\
\mathrm{Fe}^{3} \\
\mathrm{Fe}^{2} \\
\mathrm{Mn} \\
\mathrm{Mg} \\
\mathrm{Ca} \\
\mathrm{Na} \\
\text { Total }\end{array}$ & $\begin{array}{l}1.882 \\
0.032 \\
0.127 \\
0.016 \\
0.057 \\
0.169 \\
0.006 \\
0.837 \\
0.847 \\
0.028 \\
4.001\end{array}$ & $\begin{array}{l}1.846 \\
0.025 \\
0.214 \\
0.015 \\
0.053 \\
0.137 \\
0.003 \\
0.845 \\
0.838 \\
0.025 \\
4.001\end{array}$ & $\begin{array}{l}1.838 \\
0.027 \\
0.207 \\
0.019 \\
0.069 \\
0.114 \\
0.003 \\
0.861 \\
0.836 \\
0.025 \\
3.999\end{array}$ & $\begin{array}{l}1.836 \\
0.059 \\
0.145 \\
0.000 \\
0.098 \\
0.186 \\
0.008 \\
0.816 \\
0.819 \\
0.034 \\
4.001\end{array}$ & $\begin{array}{l}1.851 \\
0.046 \\
0.160 \\
0.001 \\
0.073 \\
0.211 \\
0.006 \\
0.804 \\
0.820 \\
0.028 \\
4.000\end{array}$ & $\begin{array}{l}1.886 \\
0.034 \\
0.126 \\
0.001 \\
0.064 \\
0.216 \\
0.010 \\
0.822 \\
0.811 \\
0.031 \\
4.001\end{array}$ & $\begin{array}{l}1.868 \\
0.061 \\
0.127 \\
0.002 \\
0.049 \\
0.321 \\
0.010 \\
0.719 \\
0.808 \\
0.036 \\
4.001\end{array}$ & $\begin{array}{l}1.756 \\
0.088 \\
0.239 \\
0.003 \\
0.111 \\
0.223 \\
0.008 \\
0.710 \\
0.819 \\
0.042 \\
3.999\end{array}$ & $\begin{array}{l}1.897 \\
0.044 \\
0.096 \\
0.001 \\
0.056 \\
0.220 \\
0.008 \\
0.782 \\
0.859 \\
0.035 \\
3.998\end{array}$ & $\begin{array}{l}1.867 \\
0.046 \\
0.144 \\
0.001 \\
0.064 \\
0.197 \\
0.008 \\
0.779 \\
0.857 \\
0.036 \\
3.999\end{array}$ \\
\hline $\begin{array}{l}\mathrm{Ca} \\
\mathrm{Mg} \\
\mathrm{Fe}(+\mathrm{Mn})\end{array}$ & $\begin{array}{l}44.21 \\
43.68 \\
12.10\end{array}$ & $\begin{array}{l}44.68 \\
45.04 \\
10.28\end{array}$ & $\begin{array}{r}44.38 \\
45.72 \\
9.91\end{array}$ & $\begin{array}{l}42.49 \\
42.33 \\
15.18\end{array}$ & $\begin{array}{l}42.82 \\
42.03 \\
15.15\end{array}$ & $\begin{array}{l}42.15 \\
42.74 \\
15.11\end{array}$ & $\begin{array}{l}42.38 \\
37.69 \\
19.93\end{array}$ & $\begin{array}{l}43.74 \\
37.96 \\
18.29\end{array}$ & $\begin{array}{l}44.62 \\
40.59 \\
14.79\end{array}$ & $\begin{array}{l}44.97 \\
40.88 \\
14.15\end{array}$ \\
\hline
\end{tabular}

Note: Gmass = groundmass, Mega core = megacryst core, Mega rim = megacryst rim. Phen core $=$ phenocryst core, and Microphen $=$ microphenocryst.

$\mathrm{Nb} / \mathrm{Zr}$ lavas surprisingly contain approximately constant $\mathrm{Nb}$ and $\mathrm{Zr}$ for any given $\mathrm{TiO}_{2}$. An interesting feature shown by the high $\mathrm{Nb} / \mathrm{Zr}$ lava group is that it displays a subtle, but nevertheless consistent, chemostratigraphy. The general trend is from lower to higher and then back to lower $\mathrm{Nb} / \mathrm{TiO}_{2}$ ratios upward through the succession, with the maximum value occurring at $\sim 1700 \mathrm{mbsf}$. This trend also is clearly shown by the $\mathrm{Nb} / \mathrm{Zr}$ and $\mathrm{La} / \mathrm{Sm}$ ratios (Figs. 7B and 7C). Higher $\mathrm{Nb} / \mathrm{TiO}_{2}, \mathrm{Nb} / \mathrm{Zr}$, and $\mathrm{La} / \mathrm{Sm}$ ratios are associated with more alkalic rocks; thus, the progression is from the mildly alkalic compositions at the bottom of Hole 866A to more alkalic in the middle, and finally to more tholeiitic lavas higher up. The REE-concentration patterns of Site 866 lavas (Fig. 8A) reinforce this notion.

\section{SITE 865}

A series of basaltic sills is intrusive into Albian clayey dolomitic limestones between 830 and 870 mbsf in Hole $865 \mathrm{~A}$. Two whole-rock
$\mathrm{K} / \mathrm{Ar}$ dates were determined on the sill rocks. The upper (Sample $143-865 \mathrm{~A}-93 \mathrm{R}, 13-17 \mathrm{~cm}$ ) gave an age of $87 \pm 3 \mathrm{Ma}$, and the second (Sample 143-865A-93R-4, 78-80 cm), $10 \mathrm{~m}$ lower, an age of $102 \pm 6$ $\mathrm{Ma}$ (Pringle et al., this volume). ${ }^{40} \mathrm{Ar} /{ }^{39} \mathrm{Ar}$ dates by the same authors yield an age of $111.1 \pm 2.6 \mathrm{Ma}$.

Several lines of evidence suggest that the sills were injected into unconsolidated sediments. For example, at the top of Unit 1 (Fig. 12) the overlying soft and muddy sediment becomes increasingly well indurated toward the contact. The actual contact between the basalt and the sediment is irregular and, in some places, is almost vertical, rather than horizontal (Sager, Winterer, Firth, et al., 1993, p. 149, fig. 33). Detached pieces of the clayey bioclastic limestone are included within the basalt, indicating that the latter is younger. Also, there is usually a reaction halo in the basalt where it comes in contact with the sediment, presumably the result of hydrothermal alteration during devolatilization of the wet host material. In some places (e.g., the top of Unit 4), the basalt is clearly chilled against the clayey limestone. In 
Table 2 (continued).

\begin{tabular}{|c|c|c|}
\hline 177B-1 & $177 \mathrm{~B}-1$ & $177 \mathrm{~B}-1$ \\
\hline $1-3$ & $1-3$ & $1-3$ \\
\hline (Phen core) & (Phen rim) & (Matrix) \\
\hline 40.83 & 38.70 & 37.69 \\
\hline 0.00 & 0.03 & 0.03 \\
\hline 0.07 & 0.05 & 0.06 \\
\hline 12.54 & 21.98 & 24.86 \\
\hline 0.00 & 0.37 & 0.41 \\
\hline 46.07 & 38.34 & 36.22 \\
\hline 0.28 & 0.28 & 0.35 \\
\hline 0.19 & 0.06 & 0.12 \\
\hline 99.97 & 99.80 & 99.75 \\
\hline 1.012 & 1.007 & 0.998 \\
\hline 0.002 & 0.001 & 0.001 \\
\hline 0.260 & 0.002 & 0.002 \\
\hline 0.000 & 0.478 & 0.550 \\
\hline 1.702 & 0.008 & 0.009 \\
\hline 0.007 & 1.487 & 1.429 \\
\hline 0.004 & 0.008 & 0.010 \\
\hline 0.000 & 0.001 & 0.003 \\
\hline 2.987 & 2.992 & 3.002 \\
\hline 86.7 & 75.4 & 71.9 \\
\hline
\end{tabular}

Table 3 (continued).

\begin{tabular}{|c|c|c|c|}
\hline 180R-1 & $179 R-5$ & 179R-5 & 177B-1 \\
\hline $96-100$ & $131-135$ & $51-59$ & $1-3$ \\
\hline (Gmass) & (Gmass) & (Gmass) & (Microphen) \\
\hline 49.04 & 50.74 & 51.14 & 50.19 \\
\hline 2.16 & 1.71 & 1.79 & 1.62 \\
\hline 4.04 & 2.24 & 2.42 & 3.08 \\
\hline 0.08 & 0.05 & 0.00 & 0.21 \\
\hline 1.86 & 1.93 & 1.31 & 1.93 \\
\hline 6.69 & 7.30 & 7.18 & 5.99 \\
\hline 0.22 & 0.16 & 0.18 & 0.22 \\
\hline 13.50 & 13.96 & 14.08 & 14.46 \\
\hline 21.40 & 21.46 & 21.63 & 21.80 \\
\hline 0.47 & 0.51 & 0.56 & 0.34 \\
\hline 99.46 & 100.05 & 100.27 & 99.83 \\
\hline 1.840 & 1.894 & 1.899 & 1.869 \\
\hline 0.061 & 0.048 & 0.050 & 0.045 \\
\hline 0.179 & 0.098 & 0.106 & 0.135 \\
\hline 0.002 & 0.001 & 0.000 & 0.006 \\
\hline 0.052 & 0.054 & 0.036 & 0.054 \\
\hline 0.210 & 0.228 & 0.223 & 0.187 \\
\hline 0.007 & 0.005 & 0.006 & 0.007 \\
\hline 0.755 & 0.777 & 0.779 & 0.803 \\
\hline 0.860 & 0.858 & 0.861 & 0.870 \\
\hline 0.034 & 0.037 & 0.040 & 0.024 \\
\hline 4.000 & 4.000 & 4.000 & 4.000 \\
\hline 45.65 & 44.65 & 45.19 & 45.31 \\
\hline 40.06 & 40.41 & 40.91 & 41.81 \\
\hline 14.30 & 14.95 & 13.91 & 12.88 \\
\hline
\end{tabular}

the interior of the basalt, dark reddish brown sedimentary xenoliths are completely decarbonated.

\section{Petrography and Mineralogy}

The basaltic sills are highly altered, and few of the original mineral constituents remain unaffected. There are almost certainly oxidized pseudomorphs after olivine in some specimens (e.g., Sample 143865A-93R-3, 13-17 cm), but there is no fresh relict olivine. Clinopyroxene occurs as a common groundmass constituent and is fairly well preserved. The clinopyroxenes have relatively high $\mathrm{Ca}$ in comparison with those from Hole 866A (Fig. 4 and Tables 3 and 4): they range in composition from $\mathrm{Ca}_{48} \mathrm{Mg}_{43} \mathrm{Fe}_{9}$ to $\mathrm{Ca}_{50} \mathrm{Mg}_{28} \mathrm{Fe}_{22}$ and are commonly zoned. Much of the feldspar is probably primary, and laths show a compositional spread from $\mathrm{An}_{72}$ to $\mathrm{An}_{51}$. However, some of the interstitial feldspar is secondary (e.g., the alkali feldspar [Or $\left.{ }_{96} \mathrm{Ab}_{4}\right]$ in Sample 143-865A-93R-3, 13-17 cm). Opaque oxides show a variety of textural forms, some suggestive of rapid cooling.
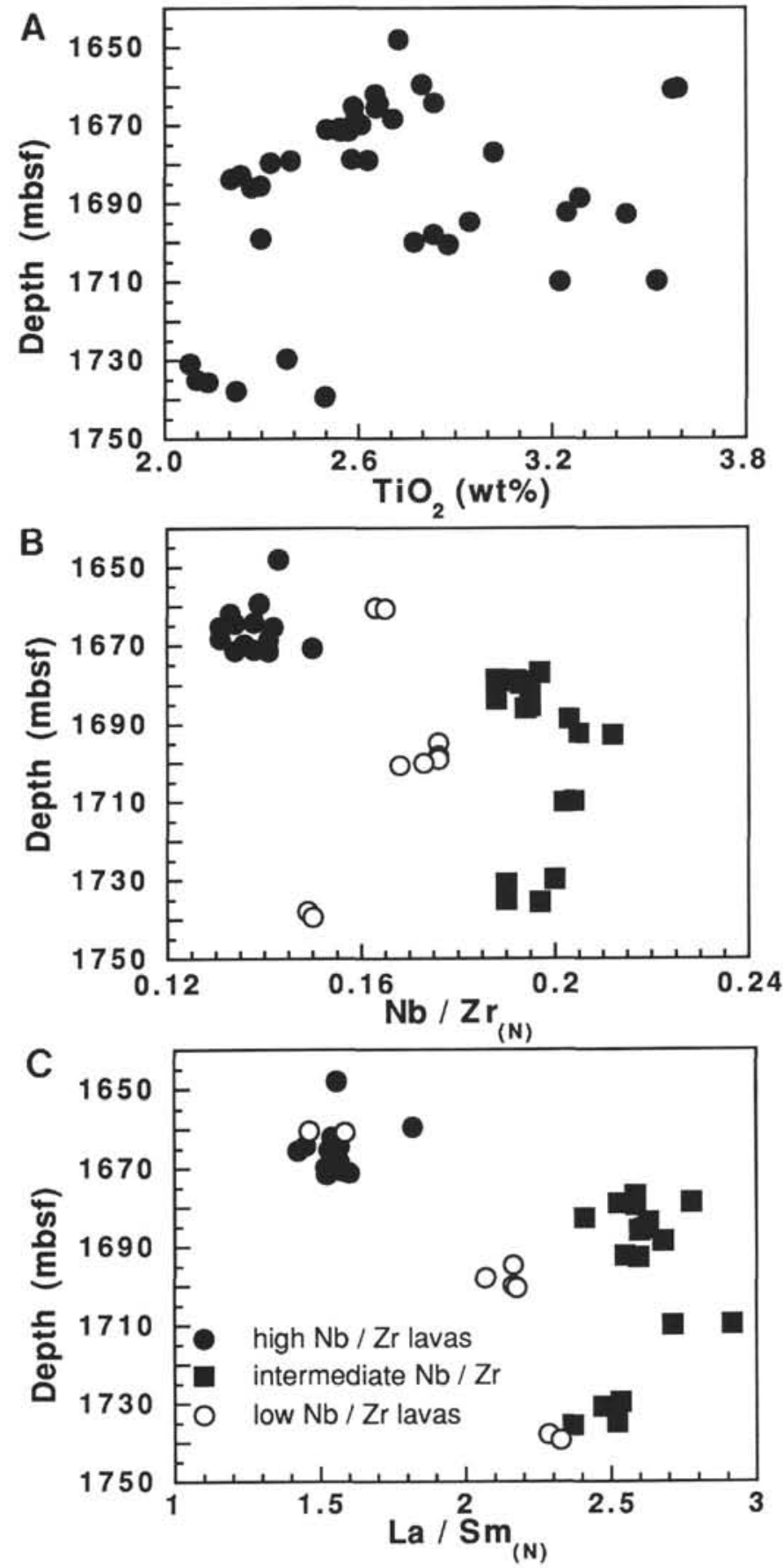

Figure 7. A. Plot of $\mathrm{TiO}_{2}$ vs. depth in Hole $866 \mathrm{~A}$. B. Plot of $\mathrm{Nb} / \mathrm{Zr}$ vs. depth in Hole 866A. C. Plot of La/Sm vs. depth in Hole 866A. In B and C, solid circles represent a high $\mathrm{Nb} / \mathrm{Zr}$ group, solid squares an intermediate $\mathrm{Nb} / \mathrm{Zr}$ group, and open circles a low $\mathrm{Nb} / \mathrm{Zr}$ group.

Compositionally, they range from titanomagnetite to ilmenite (e.g., Sample 143-865A-94R-4, 78-80 cm), and there are also some chrome spinels (e.g., Sample 143-865A-93R-3, 13-17 cm).

\section{Geochemistry}

The sills are of basaltic composition, but are so highly altered that, again, little reliance can be placed on concentrations of the more mobile elements. XRF whole-rock analyses of a selection of samples from the sills are given in Table 7. The plot of total alkalis $\left(\mathrm{Na}_{2} \mathrm{O}+\right.$ 


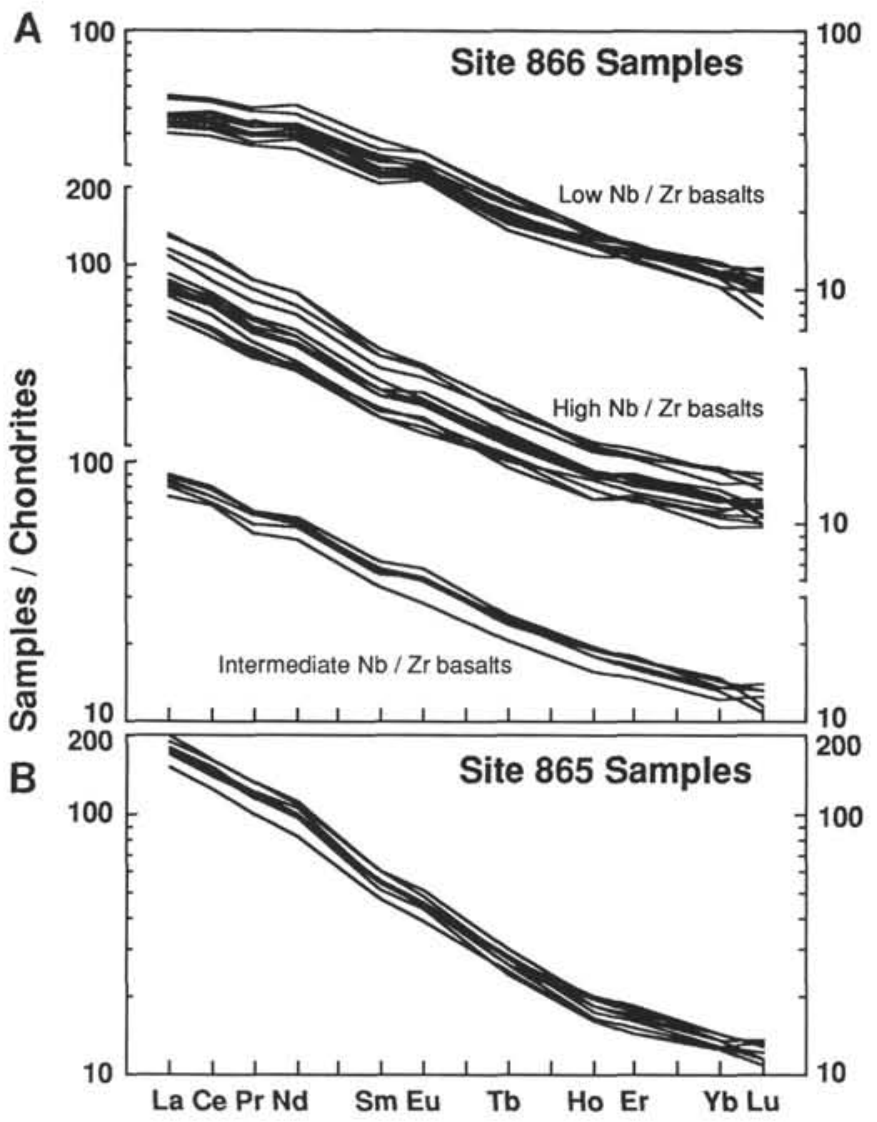

Figure 8. Chondrite-normalized REE patterns for groups of lavas from Hole $866 \mathrm{~A} \mathrm{(A)}$ and the basaltic sills of Hole 865A (B).

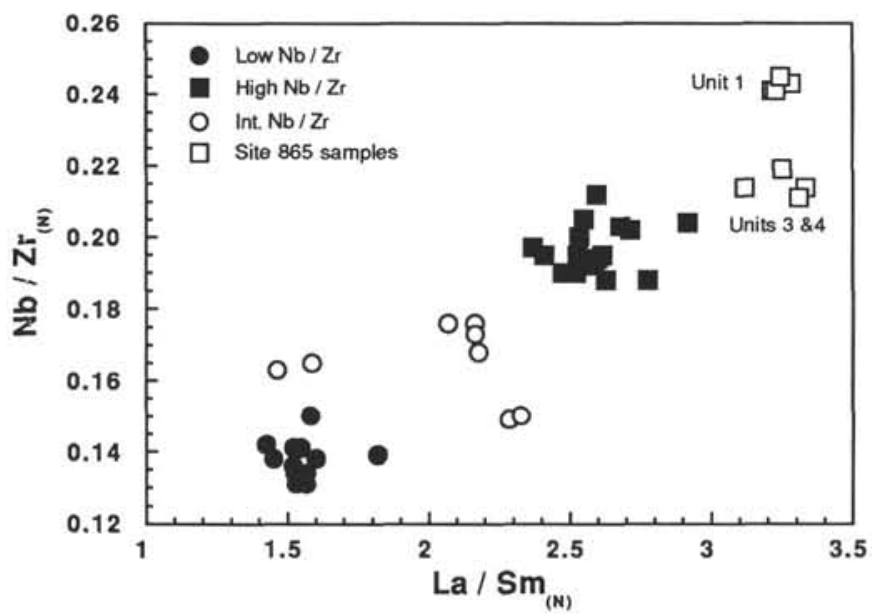

Figure 9. Plot of $\mathrm{Nb} / \mathrm{Zr}$ vs. $\mathrm{La} / \mathrm{Sm}$ for the volcanic rocks of Hole $866 \mathrm{~A}$.

$\mathrm{K}_{2} \mathrm{O}$ ) vs. $\mathrm{SiO}_{2}$ (Fig. 13) suggests that Site 865 basalts are generally more alkalic than the Site 866 basalts, but little significance can be attached to this in view of the alteration. However, chondritenormalized REE patterns of Site 865 basalts (Fig. 8B) are steep and more enriched in light REEs than those of the Site 866 lavas. In fact, chondrite-normalized trace element patterns (Fig. 14) point to greater enrichment in incompatible elements in Site 865 basalts compared with the both the Site 866 and Site 869 basalts. Although this must be treated with reservation because of the alteration, comparisons of

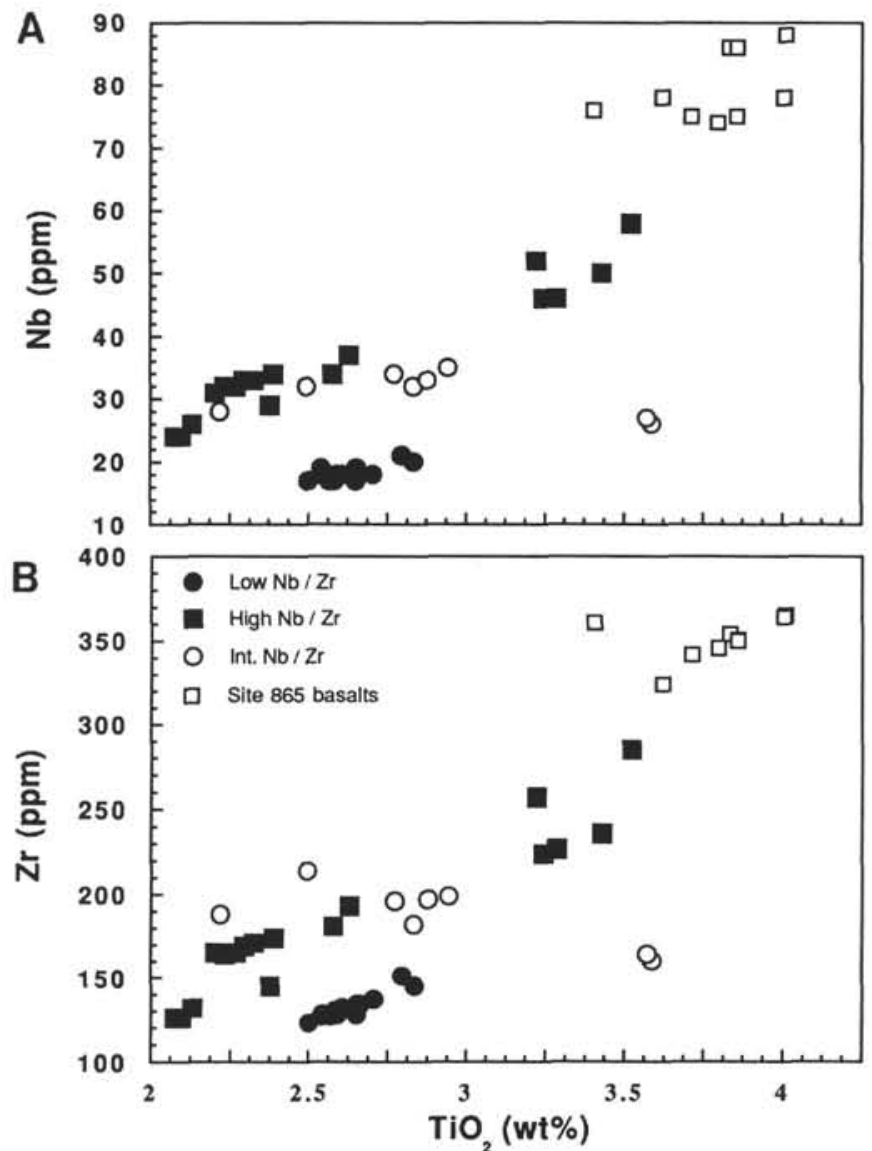

Figure 10. A. Plot of $\mathrm{Nb}$ vs. $\mathrm{TiO}_{2}$ for lavas of Hole $866 \mathrm{~A}$ and the Hole $865 \mathrm{~A}$ sills. B. Plot of $\mathrm{Zr}$ vs. $\mathrm{TiO}_{2}$ for Hole $865 \mathrm{~A}$ sills and the lavas of Hole $866 \mathrm{~A}$.

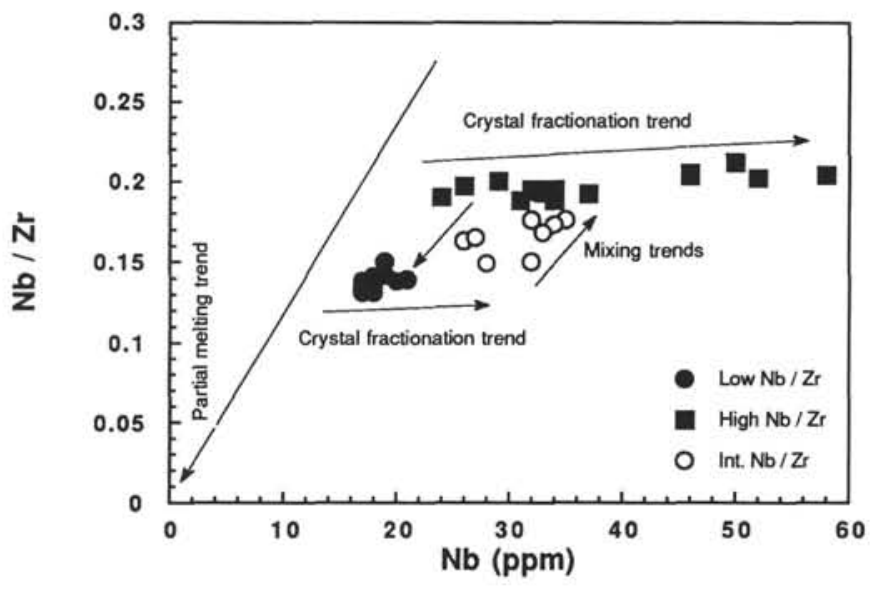

Figure 11. Plot of $\mathrm{Nb} / \mathrm{Zr}$ vs. $\mathrm{Nb}$ for the volcanic rocks of Hole 866A.

such elements suggest that Site 865 basalts are more alkalic in composition than any of the other igneous rocks drilled during Leg 143. Of more significance are the consistently higher concentrations and ratios of the alteration-resistant incompatible elements $(\mathrm{Nb}, \mathrm{Zr}, \mathrm{Ti}, \mathrm{La}$, and $\mathrm{Sm}$ ) in the Site 865 rocks. Plots of $\mathrm{Nb} / \mathrm{Zr}$ vs. La/Sm (Fig. 9), Nb vs. $\mathrm{TiO}_{2}$ (Fig. $10 \mathrm{~A}$ ), and $\mathrm{Zr}$ vs. $\mathrm{TiO}_{2}$ (Fig. 10B) illustrate the lack of overlap between basalts from the two sites and show that the Site 865 basalts have generally higher $\mathrm{Nb} / \mathrm{Zr}, \mathrm{Nb} / \mathrm{TiO}_{2}$, and $\mathrm{Zr} / \mathrm{TiO}_{2}$ ratios. The trace element signature of the Site 865 basalts is typical of highly alkalic or nephelinitic rock suites. 


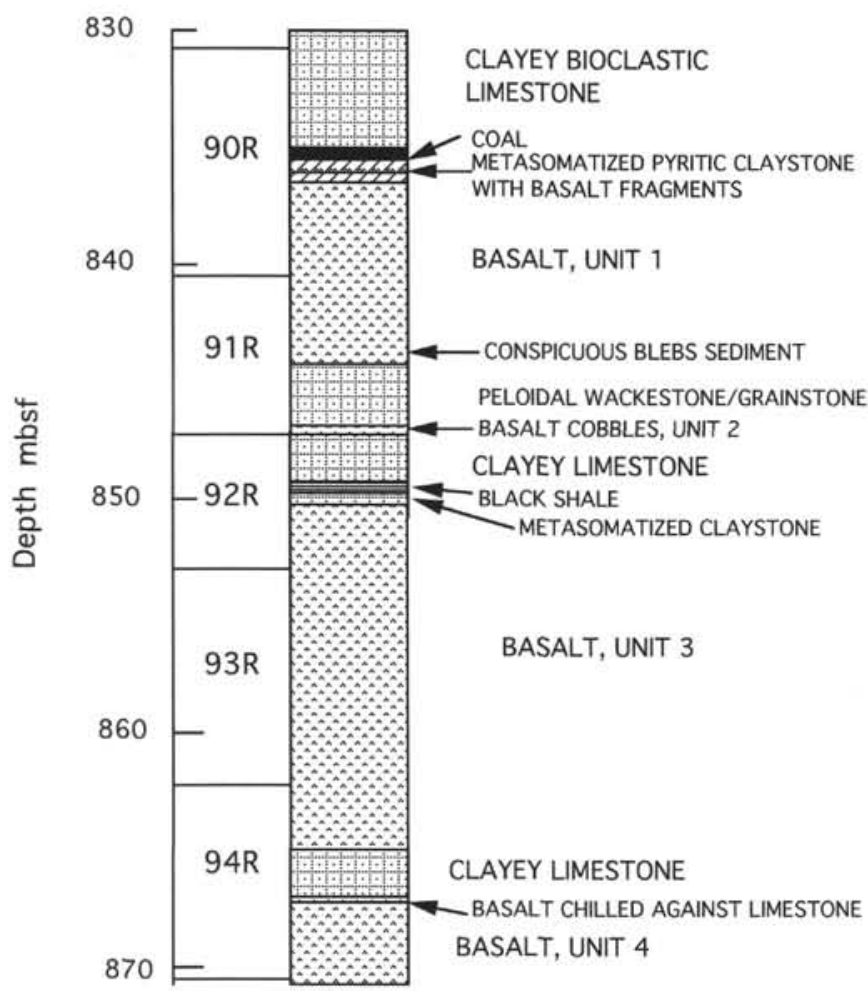

Figure 12. Simplified stratigraphic section through the basaltic sills and their host rocks, 830-870 mbsf, Allison Guyot (Hole 865A).

Site 865 samples show a slight increase in $\mathrm{La} / \mathrm{Sm}$ ratios with depth (Fig. 15A,) except for the two samples just below the sedimentary horizon located at the bottom of Section 143-865A-91R-3 to the top of Section 143-865A-92R-3 (i.e., samples from the top of Unit 3); these two samples have the lowest $\mathrm{La} / \mathrm{Sm}$ ratios of all. Basalts from the thin $(\sim 15 \mathrm{~cm}$.) Unit 2 , which are apparently interbedded with the sediments, were not analyzed because these samples are extremely altered. It was noted before, however, that Unit 2 could have been composed of cobbles from Unit 1, because they lie on top of Section 143-865A-92R (Sager, Winterer, Firth, et al., 1993). Interestingly, all Units 3 and 4 samples have similar and low $\mathrm{Nb} / \mathrm{Zr}$ ratios $(0.21-0.22)$ that are clearly distinct from the $\mathrm{Nb} / \mathrm{Zr}$ ratios $(0.24-0.25)$ of Unit 1 samples above the sediments (Figs. 9 and 15B). Unit 1 basalts also have generally higher $\mathrm{Nb} / \mathrm{TiO}_{2}$ ratios than Units 3 and 4 basalts (Fig. 10A). In summary, therefore, the general trend of Site 865 basalts is toward less alkalic composition with depth.

\section{PETROGENESIS}

The similar ratios of alteration-resistant trace elements of the geochemically enriched (i.e., high $\mathrm{Nb} / \mathrm{Zr}$ ratio) Site 866 lavas clearly suggest that samples belonging to the group are petrogenetically related through a simple magmatic differentiation mechanism. The same is true for the geochemically depleted (low $\mathrm{Nb} / \mathrm{Zr}$ ratio) group. The relationship among the mildly enriched (intermediate $\mathrm{Nb} / \mathrm{Zr}$ ) lavas is probably more complex because their geochemical characteristics overlap with both the depleted and the enriched groups. Because of the altered state of the majority of the lavas, it is difficult to evaluate quantitatively the main differentiation mechanism or mechanisms that relate samples within and between the geochemical groups. However, a plot of a ratio of two highly incompatible trace elements vs. the concentration of one of those elements can identify semiquantita-

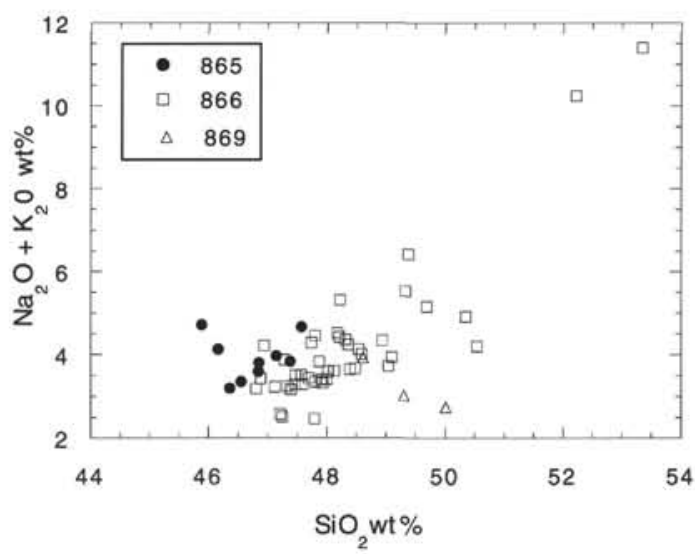

Figure 13. Total alkalis $\left(\mathrm{Na}_{2} \mathrm{O}+\mathrm{K}_{2} \mathrm{O}\right)$ vs. silica plotted for basaltic rocks of Sites 865,866 , and 869 .

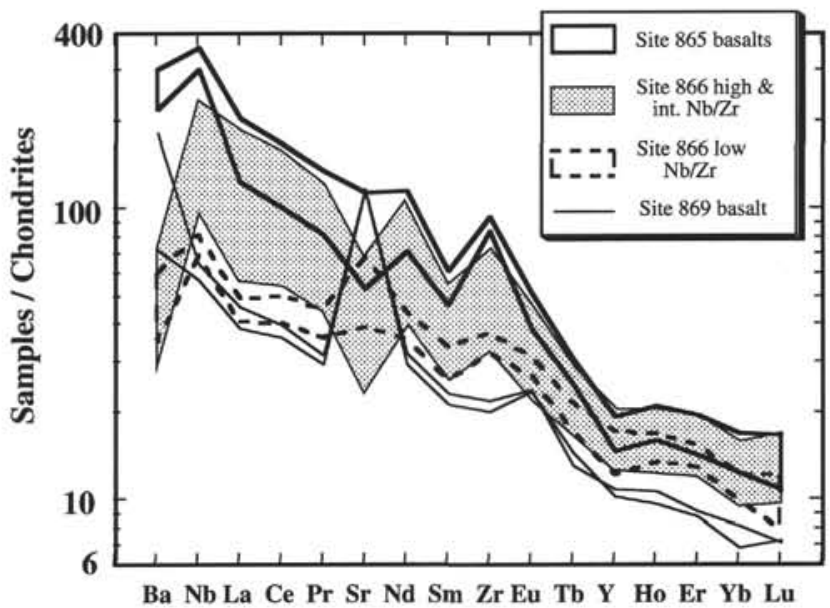

Figure 14. Comparative chondrite-normalized trace-element patterns for basalts from Sites 865,866 , and 869 .

tively such mechanisms (e.g., Minster and Allegré, 1978). Figure 11, a plot of $\mathrm{Nb} / \mathrm{Zr}$ ratios vs. $\mathrm{Nb}$, shows that the enriched and depleted Site 866 lavas define crystal fractionation trends. Figure 11 also shows it is highly unlikely that the mildly enriched lavas have their own crystal fractionation trend; rather, the lavas are probably the products of mixing between the first and second groups.

To test the crystal fractionation hypothesis for Site 866 lavas further, the major element contents of the least-altered samples, based on petrography and low LOI contents, were modeled through the leastsquares mixing program (Le Maitre, 1980) and using mineral analyses actually present in these rocks (Tables 1-5) as the fractionating phases. Two methods were employed: (1) the incremental step method, in which each differentiated rock was modeled by subtracting an appropriate combination of minerals from a slightly more mafic rock and so on until the most differentiated rock was produced and (2) the cumulative step method, in which all differentiated rocks were modeled from a single most mafic magma. Representative results of the modeling are shown in Table 8. Basically, models involving samples that have similar $\mathrm{Nb} / \mathrm{Zr}$ ratios (i.e., models between samples from within the depleted and the enriched group) produce acceptable results. The residual sum of squares of the difference in the major element contents of the actual parental rock and the parental magma predicted by the model $\left(\sum r_{i} 2\right)$ are generally $<<0.1$, except in models involving more differentiated samples, and the kind and proportion of minerals re- 
Table 4. Representative microprobe analyses (wt\% oxide) and atomic proportions of clinopyroxenes from basaltic rocks in Hole 865A. All are small grains in range $0.02-0.2 \mathrm{~mm}$.

\begin{tabular}{|c|c|c|c|c|c|c|c|c|c|c|c|}
\hline Core, section: & $94 \mathrm{R}-4$ & $94 R-4$ & $94 R-4$ & $93 R-3$ & $93 R-3$ & $93 R-3$ & $93 R-3$ & $93 R-3$ & 93R-3 & $93 R-3$ & 91R-1 \\
\hline Interval $(\mathrm{cm})$ : & $78-80$ & $78-80$ & $78-80$ & $13-17$ & $13-17$ & $13-17$ & $13-17$ & $13-17$ & $13-17$ & $13-17$ & $128-130$ \\
\hline $\mathrm{SiO}_{2}$ & 44.93 & 43.44 & 42.22 & 49.59 & 48.65 & 45.31 & 44.89 & 44.57 & 42.24 & 42.24 & 49.01 \\
\hline $\mathrm{TiO}_{2}$ & 4.70 & 5.76 & 6.64 & 2.27 & 2.45 & 3.99 & 3.97 & 4.36 & 5.08 & 5.17 & 2.33 \\
\hline $\mathrm{Al}_{2} \mathrm{O}_{3}$ & 7.47 & 7.87 & 8.17 & 4.11 & 4.12 & 7.19 & 7.16 & 7.32 & 8.46 & 8.23 & 4.07 \\
\hline $\mathrm{Cr}_{2} \mathrm{O}_{3}$ & 0.03 & 0.07 & 0.00 & 0.27 & 0.00 & 0.14 & 0.00 & 0.06 & 0.00 & 0.00 & 0.28 \\
\hline $\mathrm{Fe}_{2} \mathrm{O}_{3}$ & 2.27 & 2.12 & 2.36 & 0.97 & 3.07 & 2.39 & 3.86 & 3.57 & 5.04 & 4.12 & 2.01 \\
\hline $\mathrm{FeO}$ & 5.82 & 6.89 & 7.09 & 4.80 & 4.38 & 4.86 & 4.08 & 5.35 & 6.61 & 8.33 & 4.25 \\
\hline $\mathrm{MnO}$ & 0.12 & 0.09 & 0.20 & 0.05 & 0.14 & 0.13 & 0.21 & 0.26 & 0.17 & 0.18 & 0.04 \\
\hline $\mathrm{MgO}$ & 11.92 & 10.94 & 10.43 & 14.47 & 13.85 & 12.39 & 12.03 & 11.72 & 9.70 & 8.71 & 14.68 \\
\hline $\mathrm{CaO}$ & 22.26 & 21.60 & 21.47 & 22.62 & 22.72 & 22.54 & 22.84 & 22.13 & 21.88 & 21.70 & 22.18 \\
\hline $\mathrm{Na}_{2} \mathrm{O}$ & 0.49 & 0.64 & 0.66 & 0.37 & 0.44 & 0.39 & 0.48 & 0.51 & 0.64 & 0.72 & 0.40 \\
\hline Total & 100.00 & 99.41 & 99.25 & 99.51 & 99.83 & 99.32 & 99.53 & 99.85 & 99.83 & 99.40 & 99.24 \\
\hline $\mathrm{Si}$ & 1.687 & 1.651 & 1.615 & 1.842 & 1.814 & 1.706 & 1.692 & 1.681 & 1.615 & 1.630 & 1.827 \\
\hline $\mathrm{Ti}$ & 0.133 & 0.165 & 0.191 & 0.063 & 0.069 & 0.113 & 0.112 & 0.124 & 0.146 & 0.150 & 0.065 \\
\hline $\mathrm{Al}$ & 0.331 & 0.352 & 0.369 & 0.180 & 0.181 & 0.319 & 0.318 & 0.326 & 0.381 & 0.374 & 0.179 \\
\hline $\mathrm{Cr}$ & 0.001 & 0.002 & 0.000 & 0.008 & 0.000 & 0.004 & 0.000 & 0.002 & 0.000 & 0.000 & 0.008 \\
\hline $\mathrm{Fe}^{3}$ & 0.064 & 0.061 & 0.068 & 0.027 & 0.086 & 0.068 & 0.109 & 0.101 & 0.145 & 0.120 & 0.056 \\
\hline $\mathrm{Fe}^{2}$ & 0.183 & 0.219 & 0.227 & 0.149 & 0.137 & 0.153 & 0.129 & 0.169 & 0.211 & 0.269 & 0.132 \\
\hline $\mathrm{Mn}$ & 0.004 & 0.003 & 0.006 & 0.001 & 0.004 & 0.004 & 0.007 & 0.008 & 0.005 & 0.006 & 0.001 \\
\hline $\mathrm{Mg}$ & 0.667 & 0.620 & 0.595 & 0.801 & 0.770 & 0.695 & 0.676 & 0.659 & 0.552 & 0.501 & 0.816 \\
\hline $\mathrm{Ca}$ & 0.895 & 0.880 & 0.880 & 0.901 & 0.908 & 0.909 & 0.922 & 0.894 & 0.896 & 0.897 & 0.886 \\
\hline $\mathrm{Na}$ & 0.036 & 0.047 & 0.049 & 0.027 & 0.032 & 0.028 & 0.035 & 0.037 & 0.048 & 0.054 & 0.029 \\
\hline $\mathrm{Ca}$ & 49.39 & 49.35 & 49.55 & 47.91 & 47.66 & 49.71 & 50.05 & 48.83 & 49.5 & 50.06 & 46.84 \\
\hline $\mathrm{Mg}$ & 36.79 & 34.78 & 33.48 & 42.64 & 40.41 & 38.01 & 36.67 & 35.97 & 30.52 & 27.94 & 43.12 \\
\hline $\mathrm{Fe}(+\mathrm{Mn})$ & 13.82 & 15.86 & 16.97 & 9.45 & 11.93 & 12.28 & 13.27 & 15.2 & 19.98 & 22.00 & 10.04 \\
\hline
\end{tabular}

Note: All analyses are small grains ranging from 0.02 to $0.2 \mathrm{~mm}$.
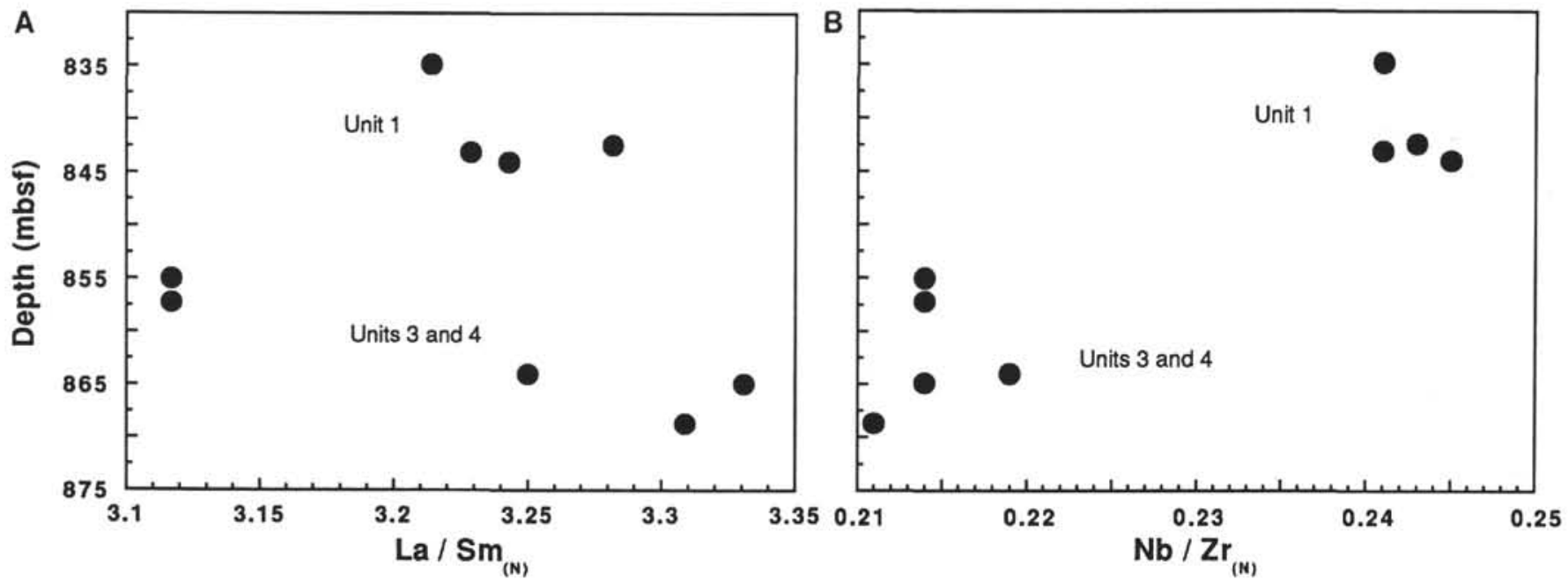

Figure 15. Plots of $\mathrm{La} / \mathrm{Sm}(\mathbf{A})$ and $\mathrm{Nb} / \mathrm{Zr}$ (B) vs. depth in Hole 865A.

moved from the parental magma are those actually present in the parental magma. Model results for samples belonging to the mildly enriched group also produce acceptable results, but only for the incremental step method because the more mafic lavas of this group have high $\mathrm{LOI}$ and $\mathrm{K}_{2} \mathrm{O}$ contents (e.g., Samples 143-866A-189R-3, 2-4 cm, and $-189 \mathrm{R}-4,11-14 \mathrm{~cm})$. Surprisingly, cumulative step results between mafic depleted basalts and differentiated mildly alkalic lavas are also acceptable. Other intragroup models produce unreasonable results.

The Site 865 basalts are more difficult to evaluate for crystal fractionation because, in addition to having fewer samples, they are generally more altered than Site 866 basalts. Specifically, the more mafic basalts have high $\mathrm{K}_{2} \mathrm{O}$ (and LOI) values so that results of cumulative models are unreasonable. Incremental model results for the differentiated basalts from Units 3 and 4 are reasonable.

In summary, major-element modeling results are consistent with the crystal fractionation origin of the intergroup $\mathrm{Nb}$ variations, shown by Site 866 depleted and enriched lavas. Modeling results for the mildly enriched lavas suggest that these rocks are possibly related through crystal fractionation, but most probably are also affected to a large extent by mixing between geochemically depleted and enriched magmas. The intermediate behavior of the trace-element contents of the mildly enriched group, between the enriched and the depleted group (e.g., Figs. 7-10), is also consistent with this mixing scenario. The geochemical variations of Site 865 basalts are subject to greater uncertainty because of alteration, but some may be attributable to simple crystal fractionation.

The above interpretations are consistent with the $\mathrm{Sr}, \mathrm{Nd}$, and $\mathrm{Pb}$ isotopic ratios of the samples (P.R. Castillo et al., unpubl. data), particularly those for the Site 866 lavas. The $\mathrm{Pb}$ and $\mathrm{Sr}$ isotopic ratios of the enriched basalts from Site 866 are generally higher than those of the depleted basalts; the $\mathrm{Sr}$ and $\mathrm{Pb}$ isotopic ratios of the mildly enriched group lie between the first two groups, supporting the suggestion from major- and trace-element data that they are likely to be mixing products. Site 865 basalts exhibit a range of isotopic values, but these do not show any systematic difference between the less alkalic Units 3 and 4 and the more alkalic Unit 1. 
Table 4 (continued),

\begin{tabular}{|c|c|c|}
\hline $91 \mathrm{R}-1$ & $91 \mathrm{R}-1$ & $91 \mathrm{R}-1$ \\
\hline $128-130$ & $128-130$ & $128-130$ \\
\hline 49.52 & 49.19 & 45.31 \\
\hline 2.43 & 2.51 & 3.64 \\
\hline 4.45 & 4.49 & 6.92 \\
\hline 0.28 & 0.21 & 0.01 \\
\hline 0.63 & 0.00 & 2.84 \\
\hline 6.12 & 6.96 & 5.47 \\
\hline 0.12 & 0.15 & 0.08 \\
\hline 13.73 & 13.67 & 11.77 \\
\hline 22.51 & 21.96 & 22.20 \\
\hline 0.40 & 0.31 & 0.54 \\
\hline 100.20 & 99.45 & 98.79 \\
\hline 1.836 & 1.839 & 1.720 \\
\hline 0.068 & 0.071 & 0.104 \\
\hline 0.195 & 0.198 & 0.310 \\
\hline 0.008 & 0.006 & 0.000 \\
\hline 0.018 & 0.000 & 0.081 \\
\hline 0.190 & 0.218 & 0.174 \\
\hline 0.004 & 0.005 & 0.003 \\
\hline 0.759 & 0.761 & 0.666 \\
\hline 0.894 & 0.880 & 0.903 \\
\hline 0.028 & 0.022 & 0.039 \\
\hline 47.97 & 47.21 & 49.42 \\
\hline 40.70 & 40.86 & 36.47 \\
\hline 11.33 & 11.93 & 14.11 \\
\hline
\end{tabular}

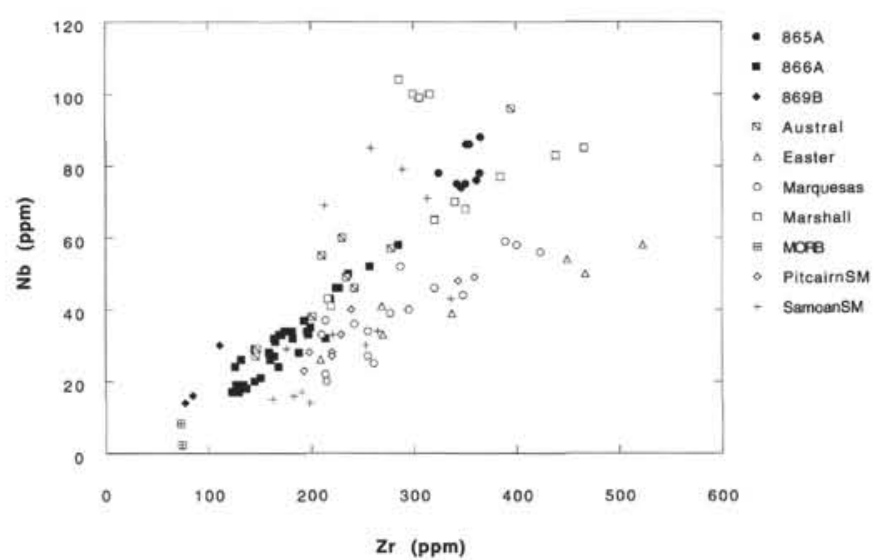

Figure 16. Plot of $\mathrm{Nb}$ vs. $\mathrm{Zr}$ for basaltic rocks of the Leg 143 sites, compared with lavas from other South Pacific seamounts and archipelagos. Sources of data as follows: Austral (Palacz and Saunders, 1986); Easter (Baker et. al., 1974); Marquesas (Woodhead, 1992); Marshall (Davis et al., 1989); MORB (Sun and McDonough, 1989); Pitcairn seamounts (Woodhead and Devey, 1993); Samoan seamounts (Johnson et al., 1986).

\section{DISCUSSION}

The basement of Site 866 was originally considered to be a sequence of subaerial lava flows with interbasaltic intervals (Sager, Winterer, Firth, et al., 1993). The latter were of various types, interpreted as rubbly aa, scoriaceous talus, debris flows, or boles. However, neither the radiometric dating (Pringle et al., this volume) nor the geochemical variations support this contention. Deviations from a systematic progression may be explained by the occurrence of intrusives within the lava pile, although evidence for this remains indirect as no intrusive contacts were recognized in the core.

Fractional crystallization is the dominant magmatic differentiation mechanism responsible for the variation of major- and trace-element contents of samples within different rock groups. These groups are most clearly distinguished on the basis of REE, $\mathrm{Nb} / \mathrm{Zr}, \mathrm{La} / \mathrm{Sm}$, and other trace-element criteria. However, the different groups must have come from different mantle sources, as implied by the geochemical evidence presented here and confirmed by their $\mathrm{Sr}, \mathrm{Nd}$, and $\mathrm{Pb}$ isotopic compositions (P.R. Castillo et al., unpubl. data).

Allison and Resolution seamounts originated within the region of the South Pacific Isotopic and Thermal Anomaly or SOPITA (Staudigel et al., 1991). SOPITA embraces the area previously designated the South Pacific Superswell (McNutt and Fischer, 1987) and includes a part of the Dupal Anomaly (Hart, 1984). It incorporates a series of island hotspots whose lavas bear the imprint of both HIMU (high U/Pb) and EMII (enriched mantle) source regions, as defined, for example, in Zindler and Hart (1986). The proportions of these components vary across the region, with EMII prevailing in the northern islands (Samoa-Marquesas) and HIMU in the more southerly hotspots, such as the Cook-Austral groups (Staudigel et al., 1991). From their work on Cretaceous seamounts, the same authors established the longevity of the anomaly by demonstrating that isotopically distinctive lavas have been generated at SOPITA for at least $120 \mathrm{~m}$.y. A more recent study by Castillo et al. (1992) pushed the isotopic anomaly even farther back, to $\sim 160 \mathrm{Ma}$. However, evidence suggests that the degree of enrichment or proportions of mantle components may not have remained constant over this long period of time. For this reason, trace element and isotopic characteristics of Cretaceous seamounts may not necessarily be used to relate them to specific presentday hotspots or island groups within the SOPITA area.

Lineaments derived by backtracking seamounts in the Pacific hotspot reference frame (Duncan and Clague, 1985; Smith et al., 1989) point to an origin of Resolution and Allison seamounts in the vicinity of the Tubuai, Society, or Tuamotu islands. Despite reservations about compositional changes with time, this link is supported by comparative plots of the immobile incompatible elements, such as $\mathrm{Nb}$ and $\mathrm{Zr}$ (Fig. 16 ). The Site 865 and 866 sills and lavas are more closely coincident with the Austral Islands lavas than with those of any other group. There is a certain amount of scatter, and the Samoan seamounts (Johnson et al., 1986) separate into trends with both high and low $\mathrm{Nb} / \mathrm{Zr}$ ratios. However, in general, high $\mathrm{Nb} / \mathrm{Zr}$ ratios are characteristic of the more westerly islands and lower ratios prevail in the east (Marquesas, Pitcairn seamounts, and Easter Island). Resolution and Allison guyots, together with the Austral Islands, lie both geographically and compositionally in the middle. In a broad sense, the incidence of more extreme alkaline compositions seems to increase toward the west across the SOPITA hotspots and their derivative seamounts. Similar east-west compositional gradations were reported by Palacz and Saunders (1986), who found that westward the islands become more enriched in large ion lithophile elements (LILE) and that they are isotopically enhanced in the Dupal components (high ${ }^{87} \mathrm{Sr} /{ }^{86} \mathrm{Sr}$, low ${ }^{143} \mathrm{Nd} /{ }^{144} \mathrm{Nd}$, and low ${ }^{207} \mathrm{~Pb} /{ }^{206} \mathrm{~Pb}$ ).

Judging by their inferred tracks (Duncan and Clague, 1985), the Resolution and Allison seamounts may have followed essentially the same path and, therefore, may have been fed at different times by the same hotspot. The lavas of Resolution Guyot show an upward shift from more alkaline to more tholeiitic compositions, which may reflect an increase in partial melting as the volcano approached and passed over a hotspot. On this basis, the alkaline sills of Allison Guyot may represent residual activity after the seamount had passed over a hotspot. But this scenario seems unlikely because light REE and other incompatible elements are more enriched as well, and the ratios tend to be slightly higher in the Site 865 sills than in the Site 866 lavas. The higher $\mathrm{La} / \mathrm{Sm}$ and $\mathrm{La} / \mathrm{Yb}$ ratios in the Site 865 basalts may be indicative of a greater depth of melt segregation. Moreover, the $\mathrm{Sr}, \mathrm{Nd}$, and $\mathrm{Pb}$ isotopic ratios of Resolution Guyot have more HIMU components than those of Allison (P.R. Castillo et al., unpubl. data). Thus, the compositional variations might be an expression of influx from two mantle components (Palacz and Saunders, 1986) whose relative contributions varied at different hotspots. It is also possible that the guyots each passed over at least two distinct hotspots. In the case of Allison Guyot, where the volcanic basement was not reached during drilling, the sills may represent a later phase of activity unrelated to the main phase of volcanism. 
Table 5. Representative microprobe analyses (wt \%) and atomic proportions of $\mathrm{Fe}$-Ti oxides and spinels from Hole 866A.

\begin{tabular}{|c|c|c|c|c|c|c|c|c|c|c|c|c|}
\hline Core, section: & 177B-1 & 177B-1 & 177B-1 & $180 \mathrm{R}-3$ & $181 R-3$ & $185 R-3$ & $180 \mathrm{R}-4$ & $171 \mathrm{R}-3$ & $185 \mathrm{R}-2$ & $185 \mathrm{R}-3$ & 189R-1 & $182 \mathrm{R}-1$ \\
\hline \multirow[t]{2}{*}{ Interval $(\mathrm{cm})$ : } & $1-3$ & $1-3$ & $1-3$ & $116-120$ & $91-96$ & $88-92$ & $1-4$ & $70-73$ & $62-66$ & $88-92$ & $66-69$ & $102-105$ \\
\hline & (Spinel) & (Ti-Mt) & (Ti-Mt) & (Ti-Mt) & (Ti-Mt) & (Ti-Mt) & (Ti-Mt) & (Ilmenite) & (Ilmenite) & (Cr-spinel) & (Cr-spinel) & (Ti-Mt) \\
\hline $\mathrm{SiO}_{2}$ & 0.05 & 0.10 & 0.05 & 0.05 & 0.41 & 0.09 & 0.03 & 0.04 & 0.01 & 0.00 & 0.00 & 0.00 \\
\hline $\mathrm{TiO}_{2}$ & 3.12 & 16.18 & 16.52 & 27.56 & 13.90 & 22.89 & 27.28 & 49.31 & 49.77 & 1.48 & 0.68 & 18.47 \\
\hline $\mathrm{Al}_{2} \mathrm{O}_{3}$ & 26.01 & 7.69 & 7.52 & 1.14 & 0.47 & 2.41 & 1.32 & 0.00 & 0.00 & 26.20 & 32.90 & 8.14 \\
\hline $\mathrm{Cr}_{2} \mathrm{O}_{3}$ & 21.48 & 9.48 & 8.91 & 0.19 & 0.37 & 5.49 & 0.13 & 0.17 & 0.00 & 31.35 & 24.61 & 1.89 \\
\hline $\mathrm{Fe}_{2} \mathrm{O}_{3}$ & 16.58 & 20.79 & 20.85 & 15.29 & 40.99 & 15.40 & 13.88 & 8.33 & 6.07 & 12.27 & 10.83 & 43.08 \\
\hline $\mathrm{FeO}$ & 21.91 & 39.27 & 39.84 & 52.63 & 39.16 & 48.55 & 51.46 & 36.36 & 40.48 & 16.18 & 19.21 & 21.61 \\
\hline $\mathrm{MnO}$ & 0.28 & 0.42 & 0.37 & 0.77 & 0.47 & 0.68 & 0.60 & 0.67 & 0.58 & 0.19 & 0.25 & 0.34 \\
\hline $\mathrm{MgO}$ & 10.86 & 4.86 & 4.71 & 2.21 & 2.41 & 1.77 & 2.37 & 4.14 & 2.07 & 12.84 & 11.30 & 6.84 \\
\hline $\mathrm{CaO}$ & 0.00 & 0.11 & 0.11 & 0.08 & 0.22 & 0.09 & 0.16 & 0.25 & 0.03 & 0.00 & 0.00 & 0.00 \\
\hline $\mathrm{NiO}$ & 0.16 & 0.05 & 0.16 & 0.00 & 0.03 & 0.07 & 0.06 & 0.00 & 0.00 & 0.13 & 0.23 & 0.18 \\
\hline $\mathrm{ZnO}$ & 0.00 & 0.00 & 0.00 & 0.08 & 0.03 & 0.19 & 0.20 & 0.00 & 0.00 & 0.11 & 0.20 & 0.01 \\
\hline Total & 100.45 & 98.95 & 99.03 & 99.99 & 98.45 & 97.62 & 97.49 & 99.28 & 99.00 & 100.74 & 100.21 & 100.54 \\
\hline $\mathrm{Si}$ & 0.002 & 0.004 & 0.002 & 0.002 & 0.015 & 0.003 & 0.001 & 0.002 & 0.000 & 0.000 & 0.000 & 0.000 \\
\hline $\mathrm{Ti}$ & 0.072 & 0.429 & 0.439 & 0.760 & 0.393 & 0.644 & 0.769 & 1.835 & 1.884 & 0.033 & 0.015 & 0.456 \\
\hline $\mathrm{Al}$ & 0.944 & 0.320 & 0.313 & 0.049 & 0.021 & 0.106 & 0.058 & 0.000 & 0.000 & 0.932 & 1.157 & 0.315 \\
\hline $\mathrm{Cr}$ & 0.523 & 0.264 & 0.249 & 0.005 & 0.011 & 0.163 & 0.004 & 0.007 & 0.000 & 0.748 & 0.581 & 0.049 \\
\hline $\mathrm{Fe}^{3}$ & 0.384 & 0.552 & 0.554 & 0.422 & 1.161 & 0.434 & 0.392 & 0.310 & 0.230 & 0.279 & 0.243 & 1.065 \\
\hline $\mathrm{Fe}^{2}$ & 0.564 & 1.158 & 1.177 & 1.613 & 1.233 & 1.520 & 1.613 & 1.504 & 1.705 & 0.408 & 0.479 & 0.594 \\
\hline Mn & 0.007 & 0.013 & 0.011 & 0.024 & 0.015 & 0.022 & 0.019 & 0.028 & 0.025 & 0.005 & 0.006 & 0.009 \\
\hline $\mathrm{Mg}$ & 0.499 & 0.255 & 0.248 & 0.121 & 0.135 & 0.099 & 0.133 & 0.306 & 0.155 & 0.577 & 0.502 & 0.335 \\
\hline $\mathrm{Ca}$ & 0.000 & 0.004 & 0.004 & 0.003 & 0.009 & 0.004 & 0.006 & 0.013 & 0.002 & 0.000 & 0.000 & 0.000 \\
\hline $\mathrm{Ni}$ & 0.004 & 0.001 & 0.004 & 0.000 & 0.001 & 0.002 & 0.002 & 0.000 & 0.000 & 0.003 & 0.006 & 0.005 \\
\hline $\mathrm{Zn}$ & 0.000 & 0.000 & 0.000 & 0.002 & 0.001 & 0.005 & 0.006 & 0.000 & 0.000 & 0.002 & 0.004 & 0.000 \\
\hline Total & 2.999 & 3.000 & 3.001 & 3.001 & 2.995 & 3.002 & 3.003 & 4.005 & 4.001 & 2.987 & 2.993 & 2.828 \\
\hline Fe number & 65.73 & 87.09 & 87.54 & 94.46 & 94.69 & 95.24 & 93.85 & 85.77 & 92.67 & 41.7 & 49.15 & 64.31 \\
\hline $\mathrm{Cr} / \mathrm{Cr}+\mathrm{Al}$ & 35.65 & 45.26 & 44.29 & 9.95 & 34.46 & 60.5 & 6.24 & 100 & 0 & 44.53 & 33.42 & 13.45 \\
\hline
\end{tabular}

Note: $\mathrm{Ti}-\mathrm{Mt}=$ titanomagnetite.

\section{ACKNOWLEDGMENTS}

We thank members of the technical staff of the Department of Earth Sciences, Leeds University, and Scripps Institution of Oceanography for the preparation of thin sections and rock crushing. In particular, we thank Alan Gray for the XRF analyses and Elizabeth Kristofetz for the ICP-MS analyses. Improvements to the manuscript were made on the basis of helpful comments by Andrew Saunders, John Sinton, and Sondra Stewart.

\section{REFERENCES}

Baker, P.E., Buckley, F., and Holland, J.G., 1974. Petrology and geochemistry of Easter Island. Contrib. Mineral. Petrol., 44:85-100.

Cann, J.R., 1970. Rb, Sr, Y, Zr, and $\mathrm{Nb}$ in some ocean floor basaltic rocks. Earth Planet. Sci. Lett., 10:7-11.

Castillo, P.R., Floyd, P.A., and France-Lanord, C., 1992. Isotope geochemistry of Leg 129 basalts: implications for the origin of the widespread Cretaceous volcanic event in the Pacific. In Larson, R.L., Lancelot, Y., et al., Proc. ODP, Sci. Results, 129: College Station, TX (Ocean Drilling Program), 405-413.

Davis, A.S., Pringle, M.S., Pickthorn, L.B.G., Clague, D.A., and Schwab, W.C., 1989. Petrology and age of alkalic lava from the Ratak Chain of the Marshall Islands. J. Geophys. Res., 94:5757-5774.

Duncan, R.A., and Clague, D.A., 1985. Pacific plate motion recorded by linear volcanic chains. In Nairn, A.E.M., Stehli, F.G., and Uyeda, S. (Eds.), The Ocean Basins and Margins (Vol. 7A): The Pacific Ocean: New York (Plenum), 89-121.

Fodor, R.V., Keil, K., and Bunch, T.E., 1975. Contributions to the mineral chemistry of Hawaiian rocks. IV. Pyroxenes in rocks from Haleakala and West Maui volcanoes, Maui, Hawaii. Contrib. Mineral. Petrol., 50:173-195.

\footnotetext{
Abbreviations for names of organizations and publications in ODP reference lists follow the style given in Chemical Abstracts Service Source Index (published by American Chemical Society).
}

Harland, W.B., Armstrong, R.L., Cox, A.V., Craig, L.E., Smith, A.G., and Smith, D.G., 1990. A Geologic Time Scale, 1989: Cambridge (Cambridge Univ. Press)

Hart, S.R., 1984. A large-scale isotope anomaly in the Southern Hemisphere mantle. Nature, 309:753-757.

Hart, S.R., Erlank, A.J., and Kable, E.J.D., 1974. Sea floor basalt alteration: some chemical and Sr isotopic effects. Contrib. Mineral. Petrol., 44:219230.

Johnson, K.T.M., Sinton, J.M., and Price, R.C., 1986. Petrology of seamounts northwest of Samoa and their relation to Samoan volcanism. Bull. Volcanol., 48:225-235.

Le Bas, M.J., 1962. The role of aluminum in igneous clinopyroxenes with relation to their parentage. Am. J. Sci., 260:267-288.

LeMaitre, R.W., 1980. A generalized petrological mixing model program. Comput. Geosci., 7:229-247.

McNutt, M.K., and Fischer, K.M., 1987. The South Pacific superswell. In Keating, B.H., Fryer, P., Batiza, R., and Boehlert, G.W. (Eds.), Seamounts, Islands, and Atolls. Geophys. Monogr., Am. Geophys. Union, 43:25-34.

Minster, J.F., and Allegré, C.J., 1978. Systematic use of trace elements in igneous processes. Part III: inverse problem of batch partial melting in volcanic suites. Contrib. Mineral. Petrol., 69:37-52.

Palacz, Z.A., and Saunders, A.D., 1986. Coupled trace element and isotope enrichment in the Cook-Austral-Samoa islands, southwest Pacific. Earth Planet. Sci. Lett., 79:270-280.

Sager, W.W., Winterer, E.L., Firth, J.V., et al., 1993. Proc. ODP, Init. Repts., 143: College Station, TX (Ocean Drilling Program).

Schweitzer, E.L., Papike, J.J., and Bence, A.E., 1979. Statistical analysis of clinopyroxenes from deep-sea basalts. Am. Mineral., 64:501-513.

Shipboard Scientific Party, 1981. Site 463: western Mid-Pacific Mountains. In Thiede, J., Vallier, T.L., et al., Init. Repts. DSDP, 62: Washington (U.S. Govt. Printing Office), 33-156.

Smith, W.H.F., Staudigel, H., Watts, A.B., and Pringle, M.S., 1989. The Magellan Seamounts: Early Cretaceous record of the South Pacific isotopic and thermal anomaly. J. Geophys. Res., 94:10501-10523.

Staudigel, H., Park, K.-H., Pringle, M., Rubenstone, J.L., Smith, W.H.F., and Zindler, A., 1991. The longevity of the South Pacific isotopic and thermal anomaly. Earth Planet. Sci. Lett., 102:24-44.

Sun, S.-S., and McDonough, W.F., 1989. Chemical and isotopic systematics of oceanic basalts: implications for mantle composition and processes. In 
Saunders, A.D., and Norry, M.J. (Eds.), Magmatism in the Ocean Basins. Geol. Soc. Spec. Publ. London, 42:313-345.

Woodhead, J.D., 1992. Temporal geochemical evolution in oceanic intra-plate volcanics: a case study from the Marquesas (French Polynesia) and comparison with other hot spots. Contrib. Mineral. Petrol., 111:458-467.

Woodhead, J.D., and Devey, C.W., 1993. Geochemistry of the Pitcairn seamounts, I: source character and temporal trends. Earth and Planet. Sci. Lett., 116:81-99.
Zindler, A., and Hart, S., 1986. Chemical geodynamics. Annu. Rev. Earth Planet. Sci., 14:493-571.

Date of initial receipt: 1 December 1993

Date of acceptance: 6 July 1994

Ms 143SR-216 
P.E. BAKER, P.R. CASTILLO, E. CONDLIFFE

Table 6. Whole-rock XRF and ICP-MS analyses of basaltic lavas from Hole 866A.

\begin{tabular}{|c|c|c|c|c|c|c|c|c|c|c|}
\hline Core, section: & $171 R-3$ & $17 \mid R-3$ & $174 \mathrm{R}-1$ & $177 \mathrm{R}-1$ & $179 \mathrm{R}-1$ & $179 \mathrm{R}-2$ & $179 \mathrm{R}-2$ & 179R-5 & 179R-5 & $179 R-5$ \\
\hline Interval $(\mathrm{cm})$ : & $70-73$ & $143-146$ & $3-5$ & $10-13$ & $108-112$ & $13-18$ & $137-140$ & $32-35$ & $51-59$ & $131-135$ \\
\hline $\mathrm{SiO}_{2}$ & 49.63 & 50.25 & 47.05 & 46.84 & 45.51 & 46.87 & 47.23 & 46.44 & 46.62 & 46.21 \\
\hline $\mathrm{TiO}_{2}^{-}$ & 2.91 & 2.77 & 2.65 & 2.76 & 3.42 & 3.45 & 2.52 & 2.75 & 2.61 & 2.51 \\
\hline $\mathrm{Al}_{2} \mathrm{O}_{3}$ & 17.29 & 16.31 & 15.25 & 15.42 & 15.12 & 15.28 & 16.61 & 16.84 & 16.80 & 16.69 \\
\hline $\mathrm{Fe}_{2} \mathrm{O}_{3}$ & 11.50 & 9.54 & 10.80 & 13.11 & 12.22 & 12.49 & 11.29 & 11.52 & 11.39 & 11.16 \\
\hline $\mathrm{MnO}$ & 0.05 & 0.08 & 0.15 & 0.17 & 0.25 & 0.23 & 0.38 & 0.24 & 0.24 & 0.16 \\
\hline $\mathrm{MgO}$ & 2.41 & 1.68 & 6.41 & 6.98 & 7.45 & 7.98 & 9.42 & 7.05 & 6.73 & 6.24 \\
\hline $\mathrm{CaO}$ & 1.22 & 2.59 & 11.07 & 9.66 & 7.01 & 6.02 & 2.48 & 8.20 & 9.94 & 10.71 \\
\hline $\mathrm{K}_{2} \mathrm{O}$ & 8.88 & 10.07 & 0.55 & 0.47 & 0.83 & 0.75 & 2.455 & 0.71 & 0.41 & 0.40 \\
\hline $\mathrm{P}_{2} \mathrm{O}_{5}$ & 0.28 & 0.22 & 0.30 & 0.29 & 0.26 & 0.25 & 0.21 & 0.25 & 0.24 & 0.24 \\
\hline LOI & 5.10 & 5.97 & 3.06 & 1.79 & 4.56 & 3.60 & 5.68 & 3.16 & 1.79 & 2.33 \\
\hline Total & 100.12 & 100.16 & 100.29 & 100.472 & 99.88 & 100.16 & 100.72 & 100.17 & 99.80 & 99.45 \\
\hline \multicolumn{11}{|c|}{ Rare earth elements (in ppm) by ICP-MS: } \\
\hline $\mathrm{La}$ & 11.3 & 12.2 & 14.7 & 14.4 & 13.6 & 13.4 & 9.7 & 11.4 & 11.3 & 10.8 \\
\hline $\mathrm{Ce}$ & 26.1 & 25.80 & 37.2 & 35.0 & 34.6 & 33.5 & 24.7 & 29.8 & 29.0 & 27.8 \\
\hline $\operatorname{Pr}$ & 3.52 & 4.06 & 5.10 & 4.65 & 4.81 & 4.72 & 3.43 & 4.15 & 4.04 & 3.81 \\
\hline $\mathrm{Nd}$ & 17.1 & 19.2 & 25.0 & 22.3 & 24.0 & 22.7 & 16.6 & 20.3 & 19.9 & 18.5 \\
\hline $\mathrm{Sm}$ & 3.81 & 4.64 & 5.93 & 4.97 & 5.84 & 5.30 & 3.95 & 4.94 & 4.55 & 4.45 \\
\hline $\mathrm{Tb}$ & 0.62 & 0.70 & 0.91 & 0.85 & 0.90 & 0.85 & 0.64 & 0.80 & 0.72 & 0.67 \\
\hline Ho & 0.70 & 0.71 & 1.06 & 1.10 & 0.96 & 0.91 & 0.76 & 0.95 & 0.89 & 0.86 \\
\hline Er & 1.79 & 1.73 & 2.92 & 2.97 & 2.45 & 2.46 & 2.20 & 2.42 & 2.52 & 2.40 \\
\hline $\mathrm{Yb}$ & 1.26 & 1.36 & 2.45 & 2.34 & 2.09 & 1.91 & 1.68 & 1.94 & 1.97 & 1.88 \\
\hline $\mathrm{Lu}$ & 0.16 & 0.19 & 0.40 & 0.35 & 0.28 & 0.24 & 0.25 & 0.31 & 0.26 & 0.26 \\
\hline \multicolumn{11}{|c|}{ Other trace elements (in ppm) by XRF: } \\
\hline $\mathrm{Ba}$ & 203 & 254 & 112 & 92 & 109 & 116 & 145 & 99 & 96 & 97 \\
\hline Co & 47 & 40 & 53 & 54 & 61 & 61 & 53 & 50 & 46 & 48 \\
\hline $\mathrm{Cr}$ & 594 & 602 & 416 & 176 & 292 & 302 & 207 & 182 & 175 & 162 \\
\hline $\mathrm{Cu}$ & 37 & 69 & 81 & 76 & 53 & 55 & 120 & 80 & 67 & 77 \\
\hline $\mathrm{Nb}$ & 22 & 22 & 24 & 21 & 26 & 27 & 17 & 20 & 18 & 17 \\
\hline $\mathrm{Ni}$ & 386 & 297 & 246 & 135 & 199 & 200 & 137 & 136 & 136 & 131 \\
\hline $\mathrm{Rb}$ & 59 & 51 & 8 & 5 & 5 & 7 & 16 & 7 & 6 & 5 \\
\hline Sc & 29 & 22 & 24 & 24 & 24 & 22 & 29 & 26 & 19 & 14 \\
\hline $\mathrm{Sr}$ & 63 & 71 & 580 & 396 & 552 & 538 & 283 & 468 & 480 & 495 \\
\hline Th & 5 & 6 & 7 & 6 & 6 & 6 & 6 & 6 & 8 & 7 \\
\hline V & 151 & 210 & 251 & 306 & 274 & 289 & 300 & 288 & 259 & 241 \\
\hline $\mathrm{Y}$ & 19 & 20 & 27 & 27 & 26 & 25 & 19 & 27 & 24 & 24 \\
\hline $\mathrm{Zn}$ & 168 & 76 & 100 & 99 & 109 & 111 & 82 & 91 & 84 & 79 \\
\hline $\mathrm{Zr}$ & 147 & 143 & 168 & 151 & 160 & 164 & 128 & 145 & 134 & 130 \\
\hline
\end{tabular}

Notes: Major oxides in weight percent $(\%)$, and trace elements in parts per million (ppm). LOI = loss on ignition. 
PETROLOGY AND GEOCHEMISTRY OF IGNEOUS ROCKS

Table 6 (continued).

\begin{tabular}{|c|c|c|c|c|c|c|c|c|c|}
\hline $179 R-6$ & 180R-1 & $180 \mathrm{R}-1$ & $180 \mathrm{R}-2$ & 180R-3 & $180 \mathrm{R}-3$ & 180R-4 & $180 \mathrm{R}-4$ & 181R-1 & $181 \mathrm{R}-2$ \\
\hline $10-13$ & $96-100$ & $132-136$ & $102-106$ & $79-82$ & $116-120$ & $1-4$ & $7-11$ & $121-125$ & $144-148$ \\
\hline 46.94 & 46.71 & 47.17 & 46.41 & 46.23 & 46.54 & 46.01 & 46.32 & 46.47 & 47.26 \\
\hline 2.60 & 2.65 & 2.54 & 2.55 & 2.48 & 2.47 & 2.52 & 2.49 & 2.84 & 2.47 \\
\hline 16.90 & 16.53 & 17.35 & 16.49 & 16.54 & 16.78 & 16.59 & 16.68 & 14.73 & 16.53 \\
\hline 11.28 & 11.80 & 10.92 & 11.64 & 11.48 & 11.60 & 11.78 & $\begin{array}{l}10.00 \\
11.49\end{array}$ & 13.97 & 11.75 \\
\hline 0.16 & 0.14 & 0.16 & 0.16 & 0.16 & 0.16 & 0.17 & 0.16 & 0.19 & 0.29 \\
\hline 6.28 & 6.32 & 5.81 & 7.02 & 7.39 & 7.56 & 7.58 & 7.23 & 7.63 & 8.59 \\
\hline 10.24 & 10.17 & 10.30 & 10.07 & 9.97 & 10.24 & 9.88 & 10.11 & 1.85 & 3.31 \\
\hline 2.93 & 2.95 & 3.03 & 2.81 & 2.69 & $\begin{array}{r}10.24 \\
2.82\end{array}$ & 2.96 & 2.79 & 1.61 & 2.67 \\
\hline 0.41 & 0.42 & 0.52 & 0.41 & 0.39 & 0.37 & 0.41 & 0.38 & 4.43 & 2.63 \\
\hline 0.24 & 0.25 & 0.23 & 0.23 & 0.22 & 0.23 & 0.24 & 0.22 & 0.38 & 0.31 \\
\hline 2.33 & 2.02 & 2.20 & 2.36 & 1.99 & 1.62 & 1.95 & 1.85 & 6.32 & 5.11 \\
\hline 100.31 & 99.96 & 100.23 & 100.15 & 99.54 & 100.39 & 100.09 & 99.72 & 100.42 & 100.92 \\
\hline 11.6 & 11.2 & 10.4 & 11.6 & 11.0 & 11.0 & 10.7 & 10.50 & 22.7 & 18.7 \\
\hline 30.6 & 28.9 & 26.6 & 27.7 & 27.7 & 277 & 26.9 & 26.90 & 51.7 & 40.6 \\
\hline 4.23 & 3.89 & 3.57 & 4.30 & 3.76 & 3.78 & 3.72 & 3.57 & 6.12 & 4.78 \\
\hline 20.6 & 19.3 & 18.1 & 19.4 & 18.6 & 19.0 & 18.6 & 17.8 & 26.3 & 20.2 \\
\hline 5.14 & 4.51 & 4.21 & 4.83 & 4.37 & 4.34 & 4.43 & 4.35 & 5.54 & 4.23 \\
\hline 1.79 & 1.65 & 1.58 & 1.75 & 1.60 & 1.57 & 1.56 & 1.60 & 1.63 & 1.49 \\
\hline 0.80 & 0.70 & 0.68 & 0.69 & 0.73 & 0.75 & 0.68 & 0.72 & 0.81 & 0.62 \\
\hline 0.93 & 0.91 & 0.85 & 0.84 & 0.86 & 0.83 & 0.83 & 0.84 & 0.99 & 0.70 \\
\hline 2.47 & 2.55 & 2.32 & 2.14 & 2.33 & 2.40 & 2.24 & 2.34 & 2.83 & 2.10 \\
\hline 2.06 & 1.94 & 1.84 & 1.71 & 1.96 & 1.83 & 1.93 & 1.95 & 2.44 & 1.59 \\
\hline 0.30 & 0.25 & 0.22 & 0.20 & 0.27 & 0.26 & 0.28 & 0.26 & 0.35 & 0.24 \\
\hline 90 & 97 & 89 & 87 & 94 & 91 & 93 & 84 & 136 & 122 \\
\hline 45 & 48 & 45 & 49 & 49 & 45 & 47 & 48 & 61 & 66 \\
\hline 192 & 173 & 206 & 192 & 192 & 183 & 167 & 187 & 402 & 455 \\
\hline 71 & 101 & 98 & 70 & 71 & 79 & 76 & 75 & 79 & 75 \\
\hline 19 & 18 & 18 & 18 & 19 & 17 & 17 & 18 & 43 & 34 \\
\hline 145 & 131 & 136 & 140 & 144 & 136 & 139 & 140 & 185 & 223 \\
\hline 6 & 5 & 4 & 5 & 5 & 5 & 5 & 5 & 25 & 19 \\
\hline 25 & 21 & 24 & 19 & 20 & 20 & 23 & 19 & 28 & 31 \\
\hline 493 & 489 & 495 & 462 & 468 & 474 & 460 & 471 & 165 & 255 \\
\hline 6 & 5 & 7 & 6 & 6 & 5 & 7 & 4 & 6 & 7 \\
\hline 261 & 242 & 261 & 269 & 255 & 236 & 241 & 250 & 328 & 308 \\
\hline 24 & 25 & 22 & 24 & 23 & 22 & 23 & 23 & 31 & 20 \\
\hline 89 & 96 & 105 & 89 & 86 & 79 & 81 & 86 & 189 & 215 \\
\hline 134 & 137 & 128 & 132 & 127 & 123 & 127 & 128 & 218 & 181 \\
\hline
\end{tabular}


Table 6 (continued).

\begin{tabular}{|c|c|c|c|c|c|c|c|c|c|c|c|}
\hline Core, section: & I8IR-3 & I8IR-3 & I8IR-3 & 182R-1 & 182R-2 & I82R-3 & $182 \mathrm{R}-3$ & I83R-1 & 184R-1 & I84R-1 & I84R-2 \\
\hline Interval $(\mathrm{cm})$; & $15-18$ & $38-41$ & $91-96$ & $3-6$ & $99-102$ & $3-6$ & $48-51$ & $143-146$ & $18-21$ & $64-66$ & $109-111$ \\
\hline $\mathrm{SiO}_{2}$ & 46.22 & 46.01 & 45.91 & 46.96 & 47.04 & 46.52 & 46.54 & 46.89 & 47.54 & 46.95 & 48.58 \\
\hline $\mathrm{TiO}_{2}^{2}$ & 2.52 & 2.30 & 2.26 & 2.19 & 2.16 & 2.24 & 2.21 & 3.19 & 3.19 & 3.34 & 2.84 \\
\hline $\mathrm{Al}_{2} \mathrm{O}_{3}$ & 16.77 & 15.44 & 15.39 & 14.85 & 15.2 & 15.14 & 14.84 & 15.04 & 15.31 & 16.29 & 15.46 \\
\hline $\mathrm{Fe}_{2} \mathrm{O}_{3}$ & 12.07 & 12.82 & 11.99 & 12.12 & 12.05 & 12.15 & 12.21 & 13.7 & 12.79 & 13.28 & 11.93 \\
\hline $\mathrm{MnO}$ & 0.20 & 0.15 & 0.25 & 0.17 & 0.17 & 0.18 & 0.16 & 0.31 & 0.31 & 0.15 & 0.16 \\
\hline $\mathrm{MgO}$ & 8.96 & 8.96 & 7.04 & 8.94 & 7.92 & 7.24 & 7.53 & 7.48 & 6.32 & 5.67 & 8.02 \\
\hline $\mathrm{CaO}$ & 3.65 & 5.99 & 10.19 & 9.20 & 9.83 & 9.64 & 10.30 & 5.86 & 8.29 & 7.03 & 4.40 \\
\hline $\mathrm{Na}_{2} \mathrm{O}$ & 2.84 & 2.75 & 3.23 & 2.74 & 2.84 & 2.98 & 2.78 & 3.49 & 3.54 & 3.58 & 3.39 \\
\hline $\mathrm{K}_{2} \mathrm{O}$ & 2.25 & 1.53 & 0.54 & 0.51 & 0.51 & 0.50 & 0.49 & 0.74 & 0.64 & 0.72 & 1.35 \\
\hline $\mathrm{P}_{2} \mathrm{O}_{5}$ & 0.37 & 0.31 & 0.31 & 0.29 & 0.29 & 0.29 & 0.31 & 0.36 & 0.37 & 0.38 & 0.35 \\
\hline $\mathrm{LOI}^{3}$ & 4.60 & 3.96 & 3.27 & 2.21 & 2.11 & 2.48 & 2.53 & 3.41 & 1.48 & 2.31 & 4.37 \\
\hline Total & 100.45 & 100.22 & 100.38 & 100.18 & 100.12 & 99.36 & 99.90 & 100.47 & 99.78 & 99.70 & 100.85 \\
\hline \multicolumn{12}{|c|}{ Rare earth elements (in ppm) by ICP-MS: } \\
\hline $\mathrm{La}$ & 22.7 & 19.5 & 21.0 & 19.3 & 19.9 & 19.9 & 20.9 & 26.5 & 28.0 & 29.4 & 19.4 \\
\hline $\mathrm{Ce}$ & 50.1 & 44.8 & 47.2 & 44.3 & 44.3 & 46.0 & 48.2 & 56.1 & 61.4 & 62.1 & 45.1 \\
\hline Pr & 5.97 & 5.24 & 5.80 & 5.21 & 5.36 & 5.42 & 5.55 & 6.98 & 7.71 & 7.71 & 5.52 \\
\hline $\mathrm{Nd}$ & 26.4 & 23.2 & 24.8 & 23.5 & 23.6 & 23.7 & 25.1 & 30.7 & 33.1 & 33.4 & 26.3 \\
\hline $\mathrm{Sm}$ & 5.55 & 4.86 & 5.11 & 5.03 & 4.76 & 4.80 & 5.07 & 6.23 & 6.91 & 7.14 & 5.63 \\
\hline $\mathrm{Eu}$ & 1.75 & 1.69 & 1.71 & 1.65 & 1.68 & 1.75 & 1.84 & 2.16 & 2.36 & 2.36 & 2.06 \\
\hline $\mathrm{Tb}$ & 0.75 & 0.76 & 0.81 & 0.76 & 0.74 & 0.79 & 0.83 & 1.02 & 1.08 & 1.07 & 0.90 \\
\hline Ho & 0.90 & 0.86 & 0.90 & 0.87 & 0.91 & 0.89 & 0.91 & 1.17 & 1.15 & 1.18 & 1.00 \\
\hline $\mathrm{Er}$ & 2.52 & 2.37 & 2.61 & 2.52 & 2.45 & 2.32 & 2.53 & 3.21 & 3.07 & 3.22 & 2.66 \\
\hline $\mathrm{Yb}$ & 2.07 & 2.01 & 2.10 & 2.11 & 2.04 & 2.08 & 2.21 & 2.61 & 2.64 & 2.86 & 2.15 \\
\hline $\mathrm{Lu}$ & 0.29 & 0.32 & 0.28 & 0.26 & 0.31 & 0.30 & 0.29 & 0.34 & 0.40 & 0.42 & 0.27 \\
\hline \multicolumn{12}{|c|}{ Other trace elements (in ppm) by XRF: } \\
\hline $\mathrm{Ba}$ & 126 & 120 & 105 & 85 & 98 & 95 & 90 & 140 & 142 & 156 & 115 \\
\hline $\mathrm{Co}$ & 58 & 56 & 52 & 54 & 54 & 48 & 54 & 56 & 51 & 55 & 53 \\
\hline $\mathrm{Cr}$ & 388 & 341 & 289 & 325 & 314 & 300 & 300 & 174 & 167 & 173 & 206 \\
\hline $\mathrm{Cu}$ & 82 & 86 & 105 & 91 & 74 & 79 & 72 & 53 & 65 & 80 & 37 \\
\hline $\mathrm{Nb}$ & 37 & 34 & 33 & 32 & 31 & 33 & 32 & 46 & 46 & 50 & 35 \\
\hline $\mathrm{Ni}$ & 227 & 221 & 235 & 221 & 222 & 216 & 210 & 121 & 110 & 118 & 140 \\
\hline $\mathrm{Rb}$ & 17 & 7 & 12 & II & 11 & 11 & 12 & 12 & 13 & 15 & 13 \\
\hline $\mathrm{Sc}$ & 35 & 26 & 26 & 27 & 25 & 25 & 25 & 29 & 30 & 34 & 27 \\
\hline $\mathrm{Sr}$ & 275 & 344 & 380 & 337 & 370 & 368 & 357 & 411 & 437 & 466 & 360 \\
\hline Th & 6 & 8 & 6 & 5 & 5 & 7 & 6 & 8 & 7 & 8 & 5 \\
\hline $\mathrm{V}$ & 280 & 255 & 234 & 241 & 236 & 251 & 220 & 375 & 352 & $359^{\circ}$ & 282 \\
\hline $\mathrm{Y}$ & 27 & 25 & 27 & 25 & 25 & 25 & 25 & 29 & 31 & 30 & 26 \\
\hline $\mathrm{Zn}$ & 125 & 81 & 113 & 95 & 95 & 96 & 86 & 113 & 111 & 114 & 101 \\
\hline $\mathrm{Zr}$ & 193 & 174 & 171 & 164 & 165 & 169 & 165 & 227 & 224 & 236 & 199 \\
\hline
\end{tabular}

Table 7. Whole-rock XRF and ICP-MS analyses of basaltic lavas from Hole 865A.

\begin{tabular}{|c|c|c|c|c|c|c|c|c|c|}
\hline Core, section: & $90 \mathrm{R}-3$ & 91R-1 & 91R-2 & $91 \mathrm{R}-3$ & 93R-2 & $93 R-3$ & $94 \mathrm{R}-1$ & $94 \mathrm{R}-2$ & $94 \mathrm{R}-4$ \\
\hline Interval $(\mathrm{cm})$ : & $102-106$ & $128-130$ & $69-71$ & $20-23$ & $14-17$ & $86-89$ & $91-94$ & $31-34$ & $134-131$ \\
\hline $\mathrm{SiO}_{2}$ & 43.33 & 44.13 & 43.95 & 43.71 & 43.53 & 45.80 & 45.01 & 42.98 & 46.11 \\
\hline $\mathrm{TiO}_{2}$ & 3.35 & 3.65 & 3.74 & 3.60 & 3.66 & 3.67 & 3.59 & 3.73 & 3.30 \\
\hline $\mathrm{Al}_{2} \mathrm{O}_{3}$ & 15.84 & 18.30 & 18.04 & 17.64 & 16.16 & 15.78 & 16.00 & 16.00 & 15.99 \\
\hline $\mathrm{Fe}_{2} \mathrm{O}_{3}$ & 10.84 & 9.35 & 9.22 & 9.38 & 11.09 & 9.17 & 9.46 & 11.16 & 9.69 \\
\hline $\mathrm{MnO}^{\circ}$ & 0.11 & 0.11 & 0.10 & 0.09 & 0.12 & 0.15 & 0.16 & 0.15 & 0.13 \\
\hline $\mathrm{MgO}$ & 10.38 & 8.47 & 9.09 & 9.57 & 8.02 & 8.45 & 8.19 & 12.39 & 7.61 \\
\hline $\mathrm{CaO}$ & 4.47 & 7.41 & 4.72 & 5.26 & 7.05 & 9.21 & 10.28 & 2.06 & 8.78 \\
\hline $\mathrm{Na}_{2} \mathrm{O}$ & 1.79 & 2.15 & 1.65 & 2.00 & 1.75 & 2.54 & 2.12 & 1.34 & 2.27 \\
\hline $\mathrm{K}_{2} \mathrm{O}$ & 1.73 & 0.90 & 2.05 & 1.35 & 2.72 & 1.17 & 1.12 & 2.51 & 2.25 \\
\hline $\mathrm{P}_{2} \mathrm{O}_{5}$ & 0.65 & 0.73 & 0.68 & 0.72 & 0.77 & 0.72 & 0.77 & 0.80 & 0.80 \\
\hline LOI & 7.89 & 4.77 & 7.35 & 6.78 & 5.46 & 3.73 & 3.38 & 7.41 & 3.14 \\
\hline Total & 100.38 & 99.97 & 100.59 & 100.10 & 100.33 & 100.39 & 100.08 & 100.53 & 100.07 \\
\hline \multicolumn{10}{|c|}{ Rare earth elements (in ppm) by ICP-MS: } \\
\hline $\mathrm{La}$ & 37.2 & 43.0 & 43.6 & 42.7 & 46.2 & 41.9 & 48.3 & 42.0 & 43.7 \\
\hline $\mathrm{Ce}$ & 79.1 & 93.3 & 96.2 & 90.7 & 102.0 & 93.5 & 103.0 & 89.6 & 93.3 \\
\hline $\operatorname{Pr}$ & 9.51 & 11.2 & 11.3 & 11.1 & 12.7 & 11.7 & 12.7 & 11.2 & 11.6 \\
\hline $\mathrm{Nd}$ & 39.0 & 46.6 & 46.1 & 45.6 & 52.1 & 49.8 & 53.7 & 46.5 & 47.2 \\
\hline $\mathrm{Sm}$ & 7.28 & 8.25 & 8.50 & 8.28 & 9.33 & 8.46 & 9.35 & 7.94 & 8.31 \\
\hline $\mathrm{Eu}$ & 2.24 & 2.62 & 2.70 & 2.63 & 2.80 & 2.66 & 2.99 & 2.50 & 2.62 \\
\hline $\mathrm{Tb}$ & 0.93 & 1.00 & 1.07 & 1.05 & 1.05 & 0.99 & 1.13 & 0.92 & 1.00 \\
\hline Ho & 0.90 & 1.11 & 1.05 & 1.14 & 0.98 & 1.04 & 1.10 & 0.92 & 0.94 \\
\hline Er & 2.37 & 2.99 & 2.72 & 3.05 & 2.63 & 2.84 & 2.93 & 2.40 & 2.50 \\
\hline $\mathrm{Yb}$ & 2.08 & 2.24 & 2.23 & 2.37 & 2.11 & 2.22 & 2.35 & 2.10 & 2.10 \\
\hline $\mathrm{Lu}$ & 0.28 & 0.30 & 0.34 & 0.33 & 0.30 & 0.29 & 0.33 & 0.34 & 0.29 \\
\hline \multicolumn{10}{|c|}{ Other trace elements (in ppm) by XRF: } \\
\hline $\mathrm{Ba}$ & 685 & 623 & 530 & 617 & 717 & 673 & 689 & 694 & 719 \\
\hline $\mathrm{Co}$ & 56 & 48 & 44 & 45 & 49 & 41 & 46 & 55 & 39 \\
\hline $\mathrm{Cr}$ & 231 & 239 & 267 & 259 & 191 & 179 & 188 & 227 & 154 \\
\hline $\mathrm{Cu}$ & 67 & 52 & 50 & 51 & 37 & 46 & 48 & 95 & 42 \\
\hline $\mathrm{Nb}$ & 78 & 86 & 88 & 86 & 75 & 74 & 75 & 78 & 76 \\
\hline $\mathrm{Ni}$ & 194 & 159 & 152 & 156 & 130 & 111 & 130 & 129 & 133 \\
\hline $\mathrm{Rb}$ & 19 & 9 & 17 & 11 & 48 & 13 & 12 & 25 & 43 \\
\hline $\mathrm{Sc}$ & 30 & 35 & 36 & 38 & 25 & 27 & 26 & 34 & 18 \\
\hline $\mathrm{Sr}$ & 526 & 797 & 562 & 711 & 668 & 742 & 827 & 383 & 748 \\
\hline Th & 9 & 9 & 10 & 11 & 9 & 8 & 10 & 11 & 11 \\
\hline V & 300 & 302 & 327 & 330 & 289 & 264 & 259 & 357 & 239 \\
\hline $\mathrm{Y}$ & 23 & 30 & 28 & 30 & 29 & 27 & 27 & 28 & 27 \\
\hline $\mathrm{Zn}$ & 85 & 87 & 126 & 92 & 81 & 75 & 78 & 74 & 79 \\
\hline $\mathrm{Zr}$ & 324 & 354 & 365 & 351 & 350 & 346 & 342 & 364 & 361 \\
\hline
\end{tabular}

Notes: Major oxides in weight percent $(\mathrm{wt} \%)$ and trace elements in parts per million (ppm). LOI = loss on ignition. 
Table 6 (continued).

\begin{tabular}{|c|c|c|c|c|c|c|c|c|c|c|c|}
\hline I85R-1 & $185 \mathrm{R}-2$ & $185 \mathrm{R}-3$ & $185 \mathrm{R}-3$ & 186R-2 & $186 \mathrm{R}-3$ & 188R-3 & $188 \mathrm{R}-4$ & 189R-1 & 189R-1 & 189R-3 & $189 \mathrm{R}-4$ \\
\hline $83-86$ & $62-66$ & $28-32$ & $88-92$ & $128-131$ & $12-15$ & $40-43$ & $29-31$ & $11-14$ & $66-69$ & $2-4$ & $11-14$ \\
\hline 48.00 & 47.47 & 47.93 & 47.60 & 47.04 & 46.17 & 44.90 & 46.25 & 45.73 & 46.06 & 48.26 & 47.07 \\
\hline 2.77 & 2.25 & 2.71 & 2.82 & 3.44 & 3.17 & 2.28 & 2.01 & 2.03 & 2.08 & 2.12 & 2.40 \\
\hline 15.58 & 15.81 & 15.09 & 15.96 & 16.40 & 15.87 & 14.26 & 12.85 & 13.13 & 13.36 & 14.69 & 16.87 \\
\hline 11.57 & 11.32 & 12.21 & 12.44 & 12.84 & 13.44 & 12.50 & 12.13 & 12.49 & 12.91 & 10.35 & 10.35 \\
\hline 0.21 & 0.18 & 0.18 & 0.25 & 0.12 & 0.15 & 0.17 & 0.22 & 0.18 & 0.20 & 0.24 & 0.27 \\
\hline 6.38 & 6.30 & 6.54 & 5.52 & 6.50 & 6.75 & 12.99 & 11.09 & 11.24 & 10.79 & 11.36 & 9.01 \\
\hline 9.03 & 10.68 & 9.07 & 9.06 & 6.48 & 8.29 & 5.52 & 9.65 & 9.35 & 9.42 & 4.18 & 5.71 \\
\hline 3.30 & 3.12 & 3.11 & 3.33 & 3.41 & 3.41 & 2.62 & 2.03 & 2.06 & 2.16 & 2.60 & 3.04 \\
\hline 0.55 & 0.47 & 0.54 & 0.60 & 1.00 & 0.73 & 0.44 & 0.35 & 0.37 & 0.36 & 1.41 & 1.13 \\
\hline 0.37 & 0.31 & 0.36 & 0.39 & 0.41 & 0.39 & 0.23 & 0.20 & 0.20 & 0.22 & 0.28 & 0.33 \\
\hline 2.78 & 2.53 & 2.30 & 1.97 & 2.47 & 1.94 & 4.35 & 3.58 & 3.09 & 2.26 & 5.04 & 3.89 \\
\hline 100.54 & 100.44 & 100.04 & 99.94 & 100.11 & 100.31 & 100.26 & 100.36 & 99.87 & 99.82 & 100.53 & 100.07 \\
\hline 19.9 & & 20.4 & 22.0 & 31.9 & 31.5 & 16.0 & 15.4 & 16.0 & 16.1 & 18.2 & 21.3 \\
\hline 47.6 & & 46.8 & 50.5 & 70.2 & 71.5 & 36.4 & 33.8 & 35.3 & 36.0 & 42.8 & 50.0 \\
\hline 6.07 & & 6.05 & 6.27 & 8.45 & 8.41 & 4.38 & 4.15 & 4.32 & 4.50 & 5.14 & 6.12 \\
\hline 27.5 & & 27.5 & 28.7 & 36.9 & 36.6 & 18.9 & 18.7 & 19.4 & 19.1 & 23.8 & 28.0 \\
\hline 6.06 & & 5.94 & 6.37 & 6.88 & 7.32 & 3.98 & 3.91 & 3.99 & 4.28 & 5.03 & 5.77 \\
\hline 2.08 & & 2.09 & 2.25 & 2.32 & 2.39 & 1.28 & 1.35 & 1.36 & 1.46 & 1.67 & 2.03 \\
\hline 0.93 & & 0.90 & 0.97 & 0.95 & 1.07 & 0.67 & 0.66 & 0.67 & 0.69 & 0.77 & 0.91 \\
\hline 1.07 & & 1.06 & 1.09 & 1.08 & 1.10 & 0.71 & 0.83 & 0.71 & 0.78 & 0.89 & 1.01 \\
\hline 2.91 & & 2.95 & 2.92 & 2.96 & 2.99 & 2.13 & 2.21 & 2.15 & 2.01 & 2.47 & 2.72 \\
\hline 2.43 & & 2.22 & 2.40 & 2.35 & 2.71 & 1.82 & 1.87 & 1.75 & 1.83 & 1.99 & 2.26 \\
\hline 0.29 & & 0.36 & 0.33 & 0.37 & 0.38 & 0.27 & 0.30 & 0.25 & 0.31 & 0.32 & 0.33 \\
\hline 104 & 100 & 102 & 108 & 175 & 149 & 72 & 68 & 87 & 76 & 76 & 126 \\
\hline 47 & 46 & 56 & 46 & 54 & 54 & 75 & 65 & 63 & 65 & 57 & 53 \\
\hline 286 & 188 & 203 & 211 & 213 & 211 & 639 & 643 & 488 & 470 & 353 & 313 \\
\hline 43 & 42 & 63 & 54 & 77 & 72 & 75 & 67 & 78 & 73 & 68 & 63 \\
\hline 32 & 28 & 34 & 33 & 58 & 52 & 29 & 24 & 24 & 26 & 28 & 32 \\
\hline 143 & 200 & 159 & 154 & 133 & 135 & 348 & 363 & 343 & 358 & 198 & 181 \\
\hline 8 & 7 & 9 & 9 & 6 & 9 & 5 & 6 & 7 & 7 & 6 & 6 \\
\hline 24 & 16 & 23 & 28 & 28 & 31 & 45 & 32 & 26 & 23 & 28 & 35 \\
\hline 417 & 434 & 408 & 449 & 500 & 491 & 296 & 266 & 284 & 294 & 306 & 403 \\
\hline 5 & 6 & 7 & 6 & 7 & 7 & 6 & 6 & 6 & 8 & 6 & 9 \\
\hline 272 & 189 & 247 & 261 & 335 & 306 & 321 & 264 & 272 & 252 & 263 & 267 \\
\hline 29 & 24 & 29 & 31 & 28 & 32 & 22 & 22 & 21 & 22 & 24 & 26 \\
\hline 109 & 84 & 107 & 105 & 104 & 103 & 111 & 88 & 91 & 91 & 110 & 184 \\
\hline 182 & 159 & 196 & 197 & 285 & 257 & 145 & 126 & 126 & 132 & 188 & 214 \\
\hline
\end{tabular}

Table 8. Least-squares mixing calculation results.

\begin{tabular}{|c|c|c|c|c|c|c|c|c|c|c|c|}
\hline Parent & Daughter & Method & $\Sigma$ & $\begin{array}{c}\mathrm{F} \\
(\%)\end{array}$ & $\begin{array}{l}\text { Oliv } \\
(\%)\end{array}$ & $\begin{array}{l}\text { Cpx } \\
(\%)\end{array}$ & $\begin{array}{l}\text { Plag } \\
(\%)\end{array}$ & $\begin{array}{c}\text { Tmag } \\
(\%)\end{array}$ & $\begin{array}{l}\mathrm{Ilm} \\
(\%)\end{array}$ & $\begin{array}{c}\text { Orth }^{\mathrm{a}} \\
(\%)\end{array}$ & Comments \\
\hline \multicolumn{12}{|c|}{ Hole 866A depleted lavas: } \\
\hline $180 \mathrm{R}-4,1-4$ & 180R-1, 132-136 & Cumulative & 0.02 & 73.5 & 7.4 & 3.7 & 13.1 & 2.4 & - & - & Reasonable fit \\
\hline $179 \mathrm{R}-6,10-13$ & $180 \mathrm{R}-1,132-136$ & Incremental & 0.01 & 97.0 & 1.6 & 1.0 & 0.2 & 0.2 & - & - & Reasonable fit \\
\hline 189R-1, 11-14 & $182 \mathrm{R}-3,3-6$ & Cumulative & 0.29 & 82.1 & 10.2 & 5.7 & 0.8 & 0.7 & - & 0.4 & Reasonable fit \\
\hline $182 \mathrm{R}-2,99-102$ & $182 R-3,3-6$ & Incremental & 0.01 & 92.2 & 2.3 & 1.7 & 2.7 & - & - & 0.6 & Reasonable fit \\
\hline \multicolumn{12}{|c|}{ Hole $866 \mathrm{~A}$ mildly enriched lavas: } \\
\hline $189 \mathrm{R}-3,2-4$ & $185 \mathrm{R}-3,88-92$ & Cumulative & 2.70 & 12.0 & 29.0 & - & 41.8 & 4 & 3.3 & 13.9 & Not good $\mathrm{b}$ and $\mathrm{c}$ \\
\hline $185 \mathrm{R}-1,83-86$ & $185 \mathrm{R}-3,88-92$ & Incremental & 0.09 & 73.2 & 4.9 & 5.4 & 13.9 & - & 1.0 & 1.6 & Not $\operatorname{good}^{\mathrm{c}}$ \\
\hline \multicolumn{12}{|c|}{ Hole $866 \mathrm{~A}$ depleted and mildly enriched lavas: } \\
\hline $180 \mathrm{R}-4,1-4$ & $185 \mathrm{R}-1,83-86$ & Cumulative & 0.01 & 61.7 & 7.0 & 6.2 & 21.6 & 3.6 & - & - & Reasonable fit \\
\hline $180 \mathrm{R}-4,1-4$ & $185 R-3,88-92$ & Cumulative & 0.01 & 61.5 & 7.0 & 6.3 & 21.5 & 3.8 & - & 一 & Reasonable fit \\
\hline \multicolumn{12}{|c|}{ Hole $866 \mathrm{~A}$ enriched and mildly enriched lavas: } \\
\hline $189 \mathrm{R}-1,11-14$ & $185 \mathrm{R}-1,83-86$ & Cumulative & 0.21 & 65.0 & 15.2 & 10.0 & 8.1 & 0.9 & - & 0.8 & Not good \\
\hline 189R-1, 11-14 & $185 R-3,88-92$ & Cumulative & 0.16 & 62.5 & 16.8 & 10.9 & 8.6 & - & - & 1.1 & Not good ${ }^{c}$ \\
\hline \multicolumn{12}{|c|}{ Hole $866 \mathrm{~A}$ enriched and depleted lavas: } \\
\hline $189 \mathrm{R}-1,11-14$ & $179 \mathrm{R}-5,51-59$ & Cumulative & 1.28 & 74.3 & 11.6 & 9.4 & - & 1.7 & - & 2.9 & Not $\operatorname{good}^{b \text { and } c}$ \\
\hline $189 \mathrm{R}-1,11-14$ & $179 \mathrm{R}-6,10-13$ & Cumulative & 0.24 & 74.3 & 14.8 & 8.3 & 0.4 & - & - & 2.1 & Not good ${ }^{c}$ \\
\hline $180 \mathrm{R}-4,1-4$ & 866A-182R-2, 99-102 & Cumulative & 0.20 & 81.6 & 2.4 & - & 13.0 & 2.4 & - & 0.7 & Not good \\
\hline $180 \mathrm{R}-4,1-4$ & $182 R-3,3-6$ & Cumulative & 0.12 & 79.8 & 3.8 & - & 13.9 & 2.1 & - & 0.4 & Not good ${ }^{\mathrm{C}}$ \\
\hline \multicolumn{12}{|l|}{ Hole $865 \mathrm{~A}$ basalts: } \\
\hline 90R-3, 102-106 & $91 \mathrm{R}-1,128-130$ & Cumulative & 2.15 & 69.1 & 14.2 & 一 & 5.7 & - & 1.3 & 9.7 & Not good $\mathrm{b}$ and $\mathrm{c}$ \\
\hline $91 \mathrm{R}-3,20-23$ & 9IR-1, 128-130 & Incremental & 2.44 & 76.1 & 7.9 & - & 8.9 & - & 1.5 & 5.6 & Not good ${ }^{b}$ and $c$ \\
\hline $90 \mathrm{R}-3,102-106$ & $94 \mathrm{R}-4,134-131$ & Cumulative & 4.80 & 4.8 & 26.8 & - & 51.0 & - & 8.4 & 9.1 & Not good ${ }^{b \text { and } c}$ \\
\hline 94R-1, 91-94 & $94 R-4,134-131$ & Incremental & 0.07 & 56.7 & 6.2 & 10.8 & 23.1 & - & 3.2 & - & Reasonable fit \\
\hline
\end{tabular}

Note: $\mathrm{F}(\%)=$ amount of liquid remaining in the system after the removal of crystals. Oliv $=$ olivine, $\mathrm{Cpx}=$ clinopyroxene, Plag = plagioclase, Tmag $=$ titanomagnetite, Ilm $=$ ilmenite, and Orth $=$ orthoclase.

a Orthoclase is generally a secondary mineral and is usually not present in fresh mafic lavas.

${ }^{b}$ Large residual errors.

${ }^{c}$ Unlikely mineral assemblage. 